\title{
Research in Computer Science in The Republic of Moldova: A Bibliometric Analysis
}

\author{
Nelly Turcan \\ Professor, PhD, Moldova State University \\ Senior Researcher, Information Society Development Institute \\ E-mail tsurcannelly@gmail.com \\ Ion Coșuleanu \\ Scientific Researcher \\ Information Society Development Institute, Republic of Moldova \\ E-mail ion.cosuleanu@idsi.md

\section{Mihai Grecu} \\ Scientific Researcher \\ Information Society Development Institute, Republic of Moldova \\ E-mail mihai.grecu@idsi.md \\ Rodica Cujba \\ Scientific Researcher \\ Information Society Development Institute \& Technical University of Moldova \\ E-mail rodica.cujba@idsi.md
}

This paper presents results of bibliometric and text-based analysis of Computer Science research output produced by academia from the Republic of Moldova during the 2013-2018 years. The authors have collected data for research output indexed in three databases: Web of Science (WoS), Scopus, and National Bibliometric Instrument (NBI). Data from these databases were collected to obtain important indicators such as total number of research papers and citations, citation impact, h-index, collaboration patterns, top institutions, authors and publication sources. A detailed comparative analysis was performed based on these data. The authors also have performed a text-based analysis on keywords of papers indexed to identify thematic trends for research in Computer Science field. The analytical results present a detailed and useful picture of the status and the competence in Computer Science research in the Republic of Moldova.

Keywords: visibility of publications; bibliometric analysis; evaluation of research activity; information technology; smart specialization; computer science

\section{Introduction}

Information and Communication Technology (ICT) has become an area of utmost importance in all social activities. ICT promotes economic growth as well as technological changes worldwide. Today, Computer Science is one of the most relevant subjects studied in universities, labs, and research institutions. This area of study represents a source of a plethora of new interdisciplinary sub-areas, while society becomes more and more dependent on ICT.

According to the International Data Corporation (IDC), the worldwide expenses for ICT, including those for new technology, will exceed 5.6 Trillion Dollars in 2021; a steady growth in ICT is forecasted until the end of the prognosis period (International Data Corporation 2018).

Until 2021, the new Third Platform technologies, including the Internet of Things solutions (IoT), robots and drones, augmented reality headsets, virtual reality (AR/VR) and 3D printers will

Revista Română de Biblioteconomie şi Ştiința Informării = Romanian Journal of Library and Information Science ISSN 2559-5490, ISSN-L 1841-1940 • Volume 15 Issue 22019 pp. 27-50 https://doi.org/10.26660/rrbsi.2019.15.2.27

This work is licensed under a Creative Commons Attribution-NonCommercial-NoDerivatives 4.0 International License 
encompass almost a quarter (23\%) of all expenses. Overall, the expenses in technological solutions on Third Platform technologies will represent more than $70 \%$ of the worldwide ICT expenses (Technologies.org. 2018).

In Europe, the European Regional Development Fund (ERDF) and The Cohesion Fund allocated over 20 billion euros for ICT in the 2014-2020 funding period. These funds will promote the development of a Digital Single Market with a tremendous growth potential of over 250 billion euros (European Commission 2019).

According to the Ministry of Economy and Infrastructure of the Republic of Moldova, the ICT sector in Moldova has become increasingly attractive for investors, registering in 2017 a $9 \%$ growth of the gross added value (highest growth recorded in the last eight years) and contributing by $7 \%$ to the GDP (Ministry of Economy and Infrastructure 2018).

Considering the above mentioned, it becomes utterly important to study Moldovan researchers' interest in ICT, through bibliometric study. This will allow to discover the human, institutional, organizational and infrastructure scientific potential for ensuring intelligent/ smart specialization in this area.

Bibliometric analysis is an important method for a better understanding of certain aspects of research results. As a science, bibliometrics represents statistical analysis of books, journals, scientific articles, publications' sources and authors. Analysis of keywords frequency, citations, total number of articles published and by certain authors are key elements for such statistical studies. After the '90s, bibliometrics has been transformed from a simple bibliographic statistics study into a separate and unique area of study (Karanatsiou et al. 2017).

This paper intends to be a bibliometric contribution to the ICT research area in the Republic of Moldova. Considering the multidisciplinary nature of the domain, the research in this area deserves much more attention and is proving that there is a sufficient scientific potential in the Republic of Moldova for the Smart specialization of the country in ICT.

\section{Computer Science: research context}

The growth rate of the number of scientific papers is determined by the level of science development. Knowledge grows exponentially, and this growth reveals the speed of science and society development (Price 1951).

One of the bibliometric approaches to the analysis of the dynamics of science is tracking of the number of scientific publications in certain areas of study and in a specific period of time. For the analysis of the development level of the specific scientific fields in the world, statistical data has been gathered concerning number of publications in various fields registered in the Scopus database for 30 years (1989-2018) and by authors from the whole world. Based on the gathered data, it was noted that the number of publications in all areas of study has been in constant growth, with the highest number of publications observed in the Medical Field (Cujba 2019). This field has maintained leadership for the last 30 years, followed in 2018 by Engineering and then Computer Science. At the same time, analysing the growth rate of the number of publications in various fields, it becomes obvious that Computer Science has registered the highest growth rate (Figure 1). This is the field where the number of published documents has increased about 13 times over the last 30 years, a $1276 \%$ overall growth, or a $43 \%$ annual growth to be exact.

The number of publications in Computer Science is expected to outrun the one in the Medical Field in just 3 years (by 2021) (Figure 2).

This forecast shouldn't come as a surprise, as nowadays ICT has entered into all areas of social activity and there is no economic field that would remain competitive without the use of information technologies. 


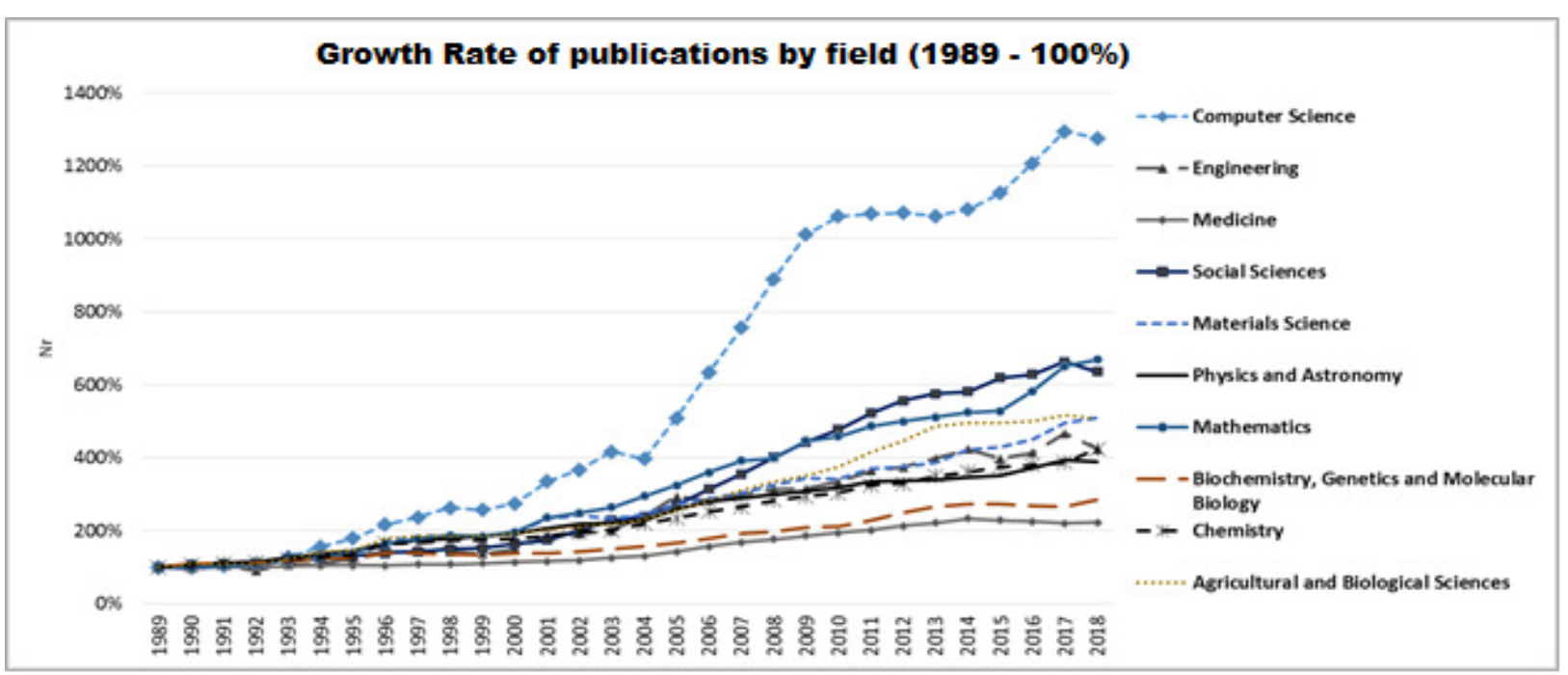

Figure 1. Growth rate of publications by field (1989 - 100\%) (Cujba 2019)

Computer Science is a relatively new (about 50 years) but a well-established and dynamic area of study. Today, it has become a highly developed, interdisciplinary science with a significant impact on other fields such as physics, mathematics, medicine, library and information science as well as other areas of study.

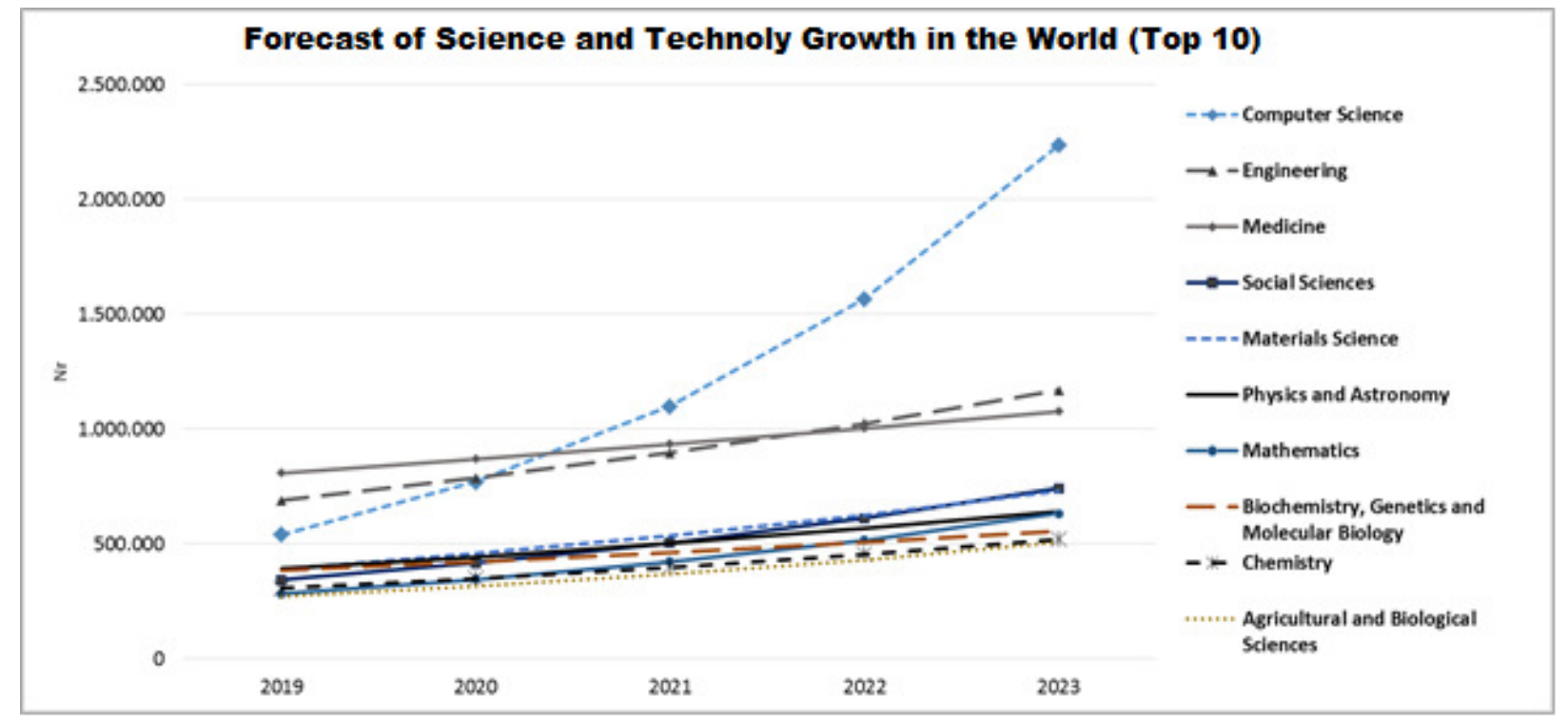

Figure 2. The forecast of Science and Technology fields growth in the world (Top 10 fields)

(Cujba 2019)

Even though ICT is in an ascending state of development, the number of bibliometric and scientometric studies in the field is relatively small, but there is, however, a certain number of such international research.

There have been published bibliometric studies in Computer Science that compare several countries (i.e.: Fiala 2012, Guan\&Ma 2004, Ma et al. 2008, Uddin\&Singh 2014, Wainer et al. 2009), or focus on a certain country such as Brazil (Arruda et al. 2009), China (Xie\&Willet 2013), India (Gupta et al. 2011, Singh et al. 2015b), Mexico (Uddin et al. 2015) and Malaysia (Bakri\&Willet 2011), or emphasizing one of the areas of Computer Science, such as Big Data (Heidari et al. 2017, Singh et al. 2015a), Cloud Computing (Heiling\&Voß 2014), Information Retrieval (Mayr and Scharnhorst 2015), or building information modelling (Zhao 2017, Qinghua 2017) etc. 
The research paper "Computer Science in Eastern Europe 1989-2014: A Bibliometric Study" (Fiala\&Willett 2015) focuses on the 15 countries of the former socialist bloc. The research reveals that between 1989 and 2014, these 15 countries (and another 11 with minimal statistical relevance to the study) produced 82,121 publications in Computer Science, with Poland being the most productive country of the region, followed by Russia, Czech Republic, Romania, Hungary and Slovenia. The publication rate grew significantly, but their quality not so much. Hungary and Slovenia are the most influential countries, based on the number of references to their research. The authors have concluded that Artificial Intelligence is the most popular area of study in Computer Science, with Interdisciplinary Applications being the category with the highest impact.

The authors that collaborate with the post-communist bloc countries are from USA, Germany, Great Britain, France and Canada, the most cited being articles having USA co-authors.

This paper (Fiala\&Willett 2015) does not include an analysis of the status of the Republic of Moldova, due to the fact that the number of Moldovan publications has not reached the 1000 threshold needed to be included in the above-mentioned analysis.

The "Research in Information and Communication Technology in Norway: Bibliometric Analysis" (Aksnes 2012) encompasses the results of a bibliometric study of the institutions included in the evaluation of the ICT research in Norway and includes institutions and departments, as well as research groups. Likewise, the report contains a macro analysis of the Norwegian research in ICT compared to the international research.

One of the most recent and extensive bibliometric studies, based on approximately 1.9 million works in Computer Science published between 1945 and 2014 that have been indexed in the Web of Science (WoS), covers a period of 70 years (Fiala\&Tutoky 2017). The study analyses the quantity as well as the impact of these publications based on the type of documents, language used, field of study, country, institutions and source of publication, as well as the most frequently used keywords, references, and the distribution of the number of references and cites. According to this study, the interdisciplinary research has the biggest impact. Therefore, the evolution of the top keywords frequency over the years is utterly interesting. The top keywords identified by this study emphasizes the evolving interest for research in these 70 years. In the more recent period, there has been evidence of an increased interest in cloud computing, optimization and security.

The recent bibliometric research regarding ICT sector situation, highlights Artificial Intelligence as the most frequent subject. Artificial Intelligence is followed by Theory \& Methods and Information Systems, with approximately $26-30 \%$ each - out of the entire pool of publications and $20-28 \%$ each - out of the entire number of references (Fiala\&Tutoky 2017). Based on the number of citations, the most influential subject is Interdisciplinary Applications, with 8 citations per study, while the overall average stands at 5.3.

The study referring to ICT in Moldova could show to what extent the research in Computer Science in the Republic of Moldova is following international trend. This study means to cover the lack of more extensive research in this sense. Hugo Hollanders' Study "Mapping of Economic, Innovative and Scientific Potential in the Republic of Moldova" (Hollanders 2017) refers as well to scientific research publications in ICT of Moldovan authors. Based on this study results, directions of smart specialization in Moldova were identified, one of them being ICT sector. Our research strives to analyse and advocate the choosing of ICT as smart specialization for our country.

\section{Scope and objectives of the study}

The main scope of this study is the evaluation of the research performance in Computer Science in the Republic of Moldova between 2013 and 2018, through the prism of Moldovan authors scientific publications. 
The specific objectives of this study:

- Examining the dynamics of national and international publications in Computer Science between 2013-2018;

- Examining the distribution of publications in ICT by scientific field;

- Identifying top ICT researchers and top ICT research institutions from the Republic of Moldova, with the main goal to ensure smart specialization in this research area;

- Analysing publication collaborations of Moldovan authors in the Computer Science field.

\section{Methodology}

For this bibliometric research, the authors used the comparative method of data analysis from two international databases (WoS and Scopus), as well as one national database - the National Bibliometric Instrument (NBI - https://ibn.idsi.md/). This particular method has been used based on the following reasons:

- Some Computer Science experts consider that WoS does not represent an agreed standard (Wainer et al. 2019, p. 536), because there is a significant amount of papers in Computer Science field published in conference materials in addition to those published in specialty journals. WoS does not index conference materials, except for those published in the Springer's Lecture Notes in Computer Science (LNCS) series and those presented within the ASIST conference. There are worldly recognized journals in Computer Science that are not indexed in WoS, such as ACM Journal on Experimental Algorithms, ACM Transactions on Algorithms, Journal of Discrete Algorithms.

- Scopus is a scientific database that offers, perhaps, a better image of the production side of Computer Science, because it indexes the set of ACM (Association of Computer Machinery), IEEE (Institute of Electrical and Electronics Engineers) and Elsevier journals, but also certain ACM and IEEE conferences, as well as the LNCS series, that are being indexed both as a journal and as conferences materials (Wainer et al. 2019, p. 536).

- There have been other studies that tried to compare WoS and Scopus (Chadegani et al. 2013). These researches were focused on comparing coverage, bias in coverage and mostly the difference in the results of citations' analysis. This article uses data sources from WoS and Scopus, aiming to compare the way these two databases index publications in Computer Science with authors from the Republic of Moldova, as well as papers indexed in the national database.

The WoS data were collected on February 8-9 2019 (Web of Science 2019), using an advanced search procedure. The following criteria were used for searching information on computer science publications in the WoS database:

(1) Country affiliation (CU=Moldova);

(2) Period (PY=2013-2018);

(3) Result filtering based on WoS categories (Computer Science Categories Field) [1]

- Computer Science, Artificial Intelligence;

- Computer Science, Cybernetics;

- Computer Science, Hardware \& Architecture;

- Computer Science, Information Systems;

- Computer Science, Interdisciplinary Applications;

- Computer Science, Software Engineering;

- Computer Science, Theory \& Methods;

- Imaging Science \& Photographic Technology;

- Telecommunications;

- Information Science \& Library Science. 
The data obtained from Scopus database were gathered on February 8-9, 2019 (Scopus 2019), using the simple search option. The query was based on the following criteria:

(1) Country Affiliation (Moldova);

(2) Period 2013-2018;

(3) The obtained results have been filtered based on the research field (Computer Science).

The data obtained from the National Bibliometric Instrument, developed and maintained by the Information Society Development Institute, were collected on February 8-11 2019 (National Bibliometric Instrument 2019). For the NBI data selection, we used the advanced search function of the open resource http://stiu.md/ (Știu.md 2019), as well as the informative panel of NBI. For obtaining the above-mentioned data, the following criteria have been used:

(1) The Science and Technology of Computers. Computers. Data processing (based on the Universal Decimal Classification - UDC);

(2) Period 2013-2018;

(3) The affiliation country of the authors (Moldova).

\section{Results}

Between 2013 and 2018, there were 1,524,151 documents identified in the WoS database, that can be classified in the Computer Science categories, with subcategories in the same area of study, as well as other subcategories that are relevant to this study, but are not part of the Computer Science category, such as: Imaging Science \& Photographic Technology; Information Science \& Library Science; Telecommunications. Out of all international publications in Computer Science found in WoS, $169(0.011 \%)$ belong to the authors from the Republic of Moldova.

The authors found in WoS 3,345 documents published by Moldovan authors between 2013 and 2018, out of which 169 were researches in Computer Science. This represents $5.05 \%$ out of the total number of publications coming from the Republic of Moldova in the above-mentioned period.

A similar situation regarding publications by Moldovan authors has been observed in the Scopus database. Between 2013 and 2018 there has been a total of 2,779,218 works in Computer Science published in the Scopus. Those belonging to the Republic of Moldova (225) represent $0.008 \%$. From the total of 2,905 publications by Moldovan authors in this period, the ones referring to Computer Science represent 7.75\%.

At the moment of data collection from NBI, there were a total of 69,640 documents found, out of which 48,937 (70.3\%) had at least one author from the Republic of Moldova. Likewise, out of the total number of documents $(69,640)$, approximately $57.4 \%(40,005)$ were works published between 2013 and 2018, and out of the above-mentioned papers 26,867 (67.2\%) belong to authors from Moldova. In the fields - Computer Science and Technology. Computers. Data Processing which are relevant to Computer Science, there were 496 papers (1.86\%) published by Moldovan authors in 2013-2018, indexed in NBI.

Therefore, the percentage of publications by Moldovan authors in Computer Science field, in all three databases between 2013 and 2018, is not very high: WoS - 5.05\%, Scopus $7.75 \%$ and NBI $1.86 \%$.

The comparative analysis of the indexing dynamics of publications in WoS, Scopus and NBI shows that there were slightly more documents in Computer Science found in the Scopus database (Figure 3). The Scopus indexing dynamics is positive, with the greatest number of published works recorded in 2018 (48 publications). 


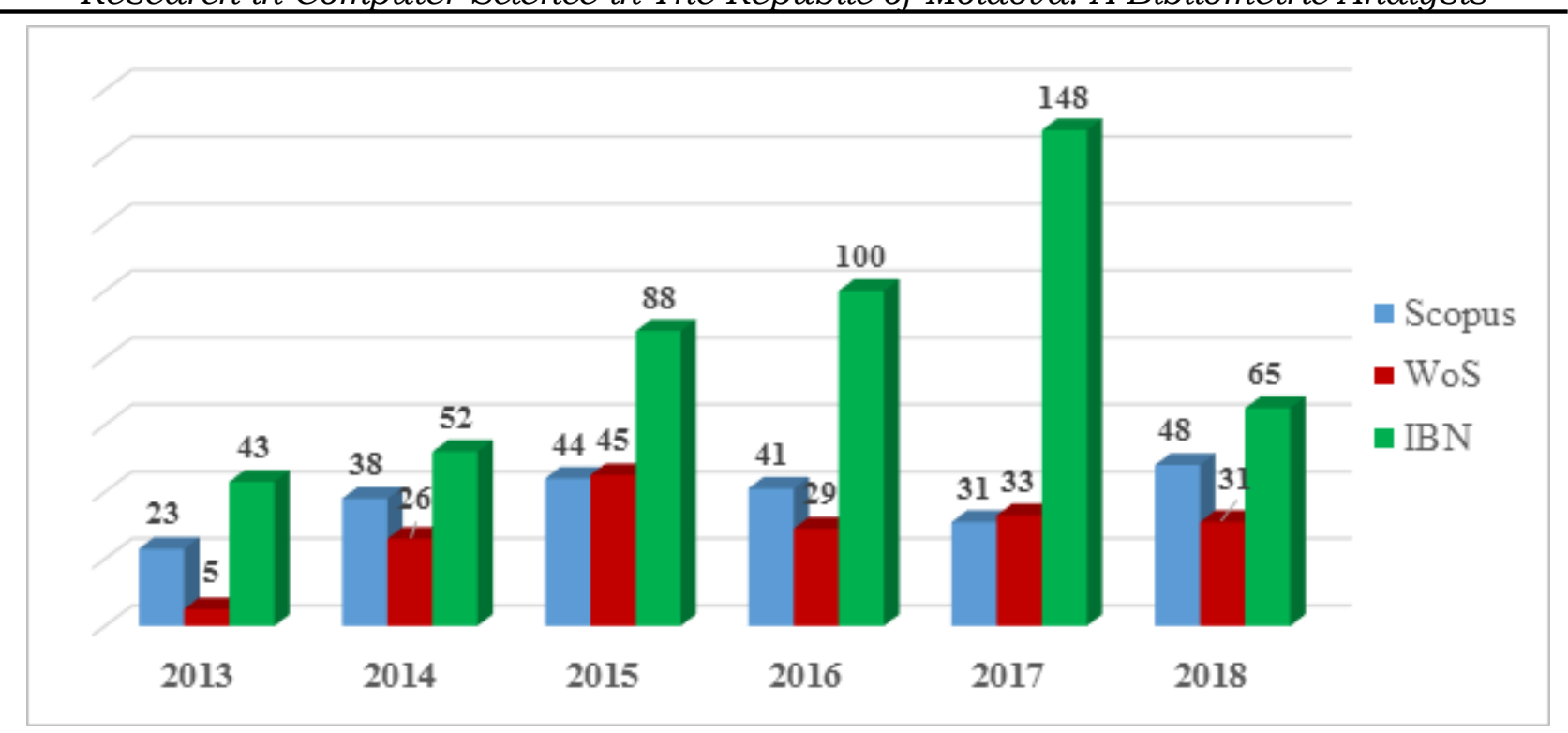

Figure 3. The dynamics of the publications in Computer Science recorded in WoS, Scopus and NBI

As far as NBI goes, we can, as well, observe some positive dynamics in documents publication. The relatively small number for 2018 can be explained by the delayed effect of the actual publication process.

We can also note that the growth rate of publications in the Computer Science field in Moldova is mostly positive (Table 1). The number of works in Computer Science published in the WoS database has increased six-fold, Scopus recorded a more than $100 \%$ growth, while NBI registered 1.5 times more works in the studied timeframe.

Table 1. Details regarding publications in Computer Science Field in WoS, Scopus and NBI

\begin{tabular}{|l|c|c|c|c|c|c|c|c|c|}
\hline & \multicolumn{3}{|c|}{ WoS } & \multicolumn{3}{c|}{ Scopus } & \multicolumn{3}{c|}{ NBI } \\
\cline { 2 - 10 } \\
Year & $\begin{array}{c}\text { Number } \\
\text { of publi- } \\
\text { cations }\end{array}$ & \% & $\begin{array}{c}\text { Average } \\
\text { annual } \\
\text { growth } \\
\text { rate (\%) }\end{array}$ & $\begin{array}{c}\text { Number } \\
\text { of publi- } \\
\text { cations }\end{array}$ & \% & $\begin{array}{c}\text { Average } \\
\text { annual } \\
\text { growth } \\
\text { rate (\%) }\end{array}$ & $\begin{array}{c}\text { Number } \\
\text { of publi- } \\
\text { cations }\end{array}$ & \% & $\begin{array}{c}\text { Average } \\
\text { annual } \\
\text { growth } \\
\text { rate (\%) }\end{array}$ \\
\hline 2013 & 5 & 3.0 & - & 23 & 10.2 & - & 43 & 8.7 & - \\
\hline 2014 & 26 & 15.4 & 420 & 38 & 16.9 & 65.2 & 52 & 10.5 & 20.9 \\
\hline 2015 & 45 & 26.6 & 73.1 & 44 & 19.5 & 15.8 & 88 & 17.7 & 69.2 \\
\hline 2016 & 29 & 17.2 & -35.6 & 41 & 18.2 & -6.8 & 100 & 20.2 & 13.6 \\
\hline 2017 & 33 & 19.5 & 13.8 & 31 & 13.8 & -24.4 & 148 & 29.8 & 48.0 \\
\hline 2018 & 31 & 18.3 & -6.1 & 48 & 21.3 & 54.8 & 65 & 13.1 & -56.1 \\
\hline Total & 169 & 100 & 465.3 & 225 & 100 & 104.6 & 496 & 100 & 95.7 \\
\hline
\end{tabular}

Most of WoS publications in Computer Science with authors from the Republic of Moldova are distributed by following subcategories: Theory \& Methods (45\%), Artificial Intelligence (26.6\%), Interdisciplinary Applications (20.7\%), Information Systems (18.3\%). Theory \& Methods is the most prolific subcategory, with 76 indexed documents (Figure 4). In the studied period, there were no publications by authors from Moldova in Cybernetics. The only paper registered in this subcategory was published in 2011 .

Likewise, we can note that some publications in Computer Science are also registered in other 
interfering categories such as Applied Mathematics (15.4\%), Electronic \& Electric Engineering $(15.4 \%)$.

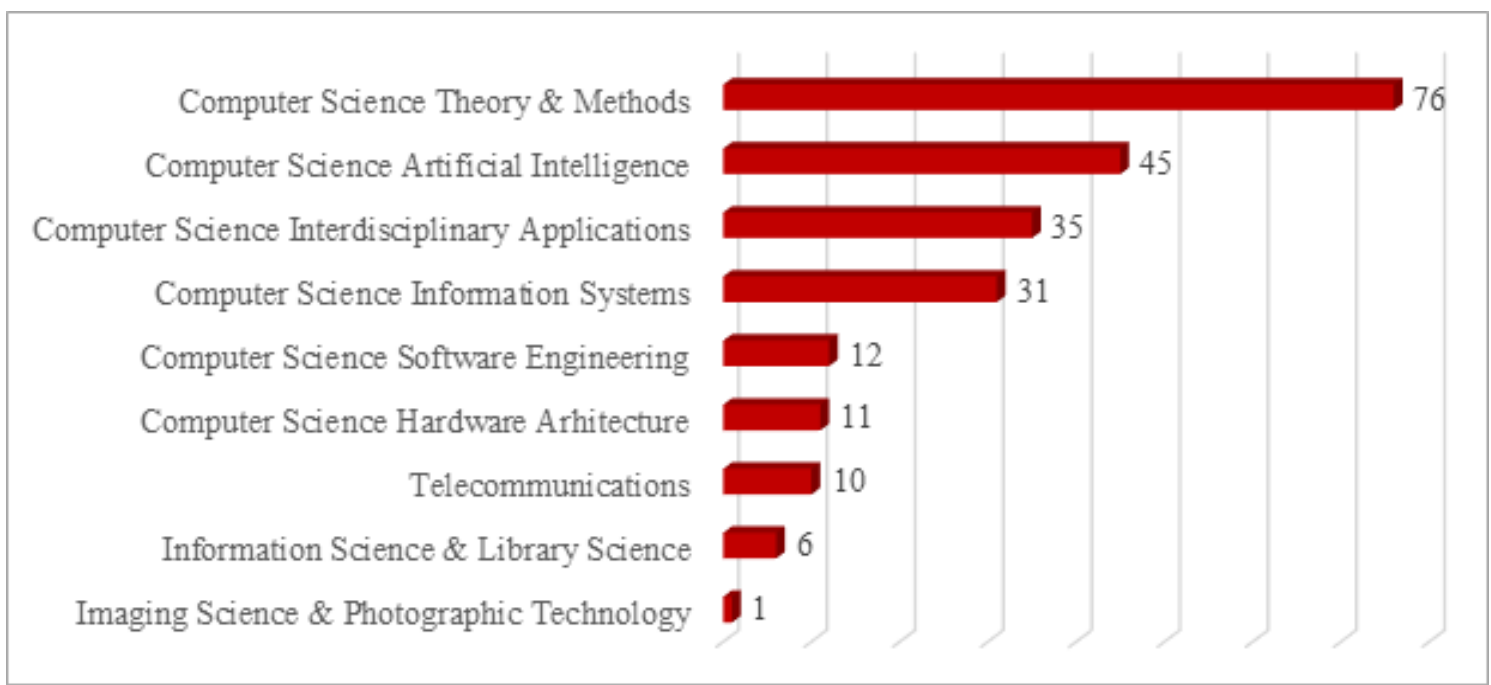

Figure 4. Distribution of WoS publications in Computer Science by subcategories

We have to mention that the international articles in Computer Science published by authors from the Republic of Moldova are not very influent. Their most influent works refer to the following subcategories: Theory \& Methods - approximately $26 \%$ out of the total number of citations; Artificial Intelligence - approximately $12 \%$ and Software Engineering - approximately $12 \%$. The highest quotation average per article was recorded in the Engineering Software category and stands at 2.4 references per article, compared to other WoS categories where the referencing average of Moldovan authors is very low. In the study period, the average quotation per article rate is 0.7 . According to the WoS data, in 2013-2018, the most cited works published by authors from the Republic of Moldova are grouped in the following categories: Physical Chemistry - 13.4 citations per article; The Science of Interdisciplinary Materials - 11.4 citations per articles; Condensed Matter Physics - 9.9 citations per article.

The analysis of Scopus database papers by category shows that many documents in Computer Science overlap with other exact, applicative and social sciences categories (Figure 5). The biggest percentage is registered by publications in Mathematics (46.2\%), Engineering (44.4\%), Physics and Astronomy (25.8\%), the Materials Science (19.6\%). We can ascertain differences in the distribution by category of the publications in WoS and Scopus. At the moment of analysis, there were 26 publications in Mathematics in WoS database vs 104 in Scopus; WoS recorded 34 documents in Engineering, while Scopus registered 100.

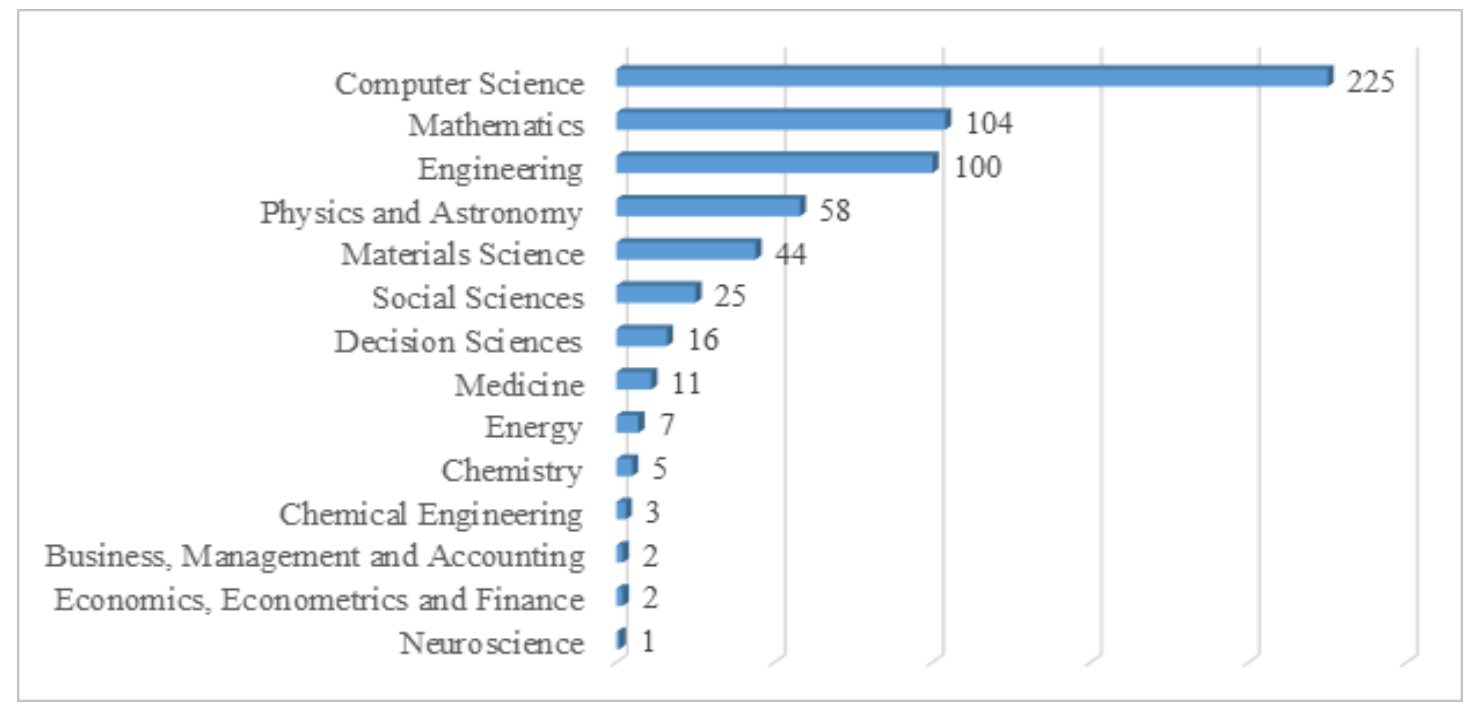

Figure 5. The distribution of documents by category (Scopus) 


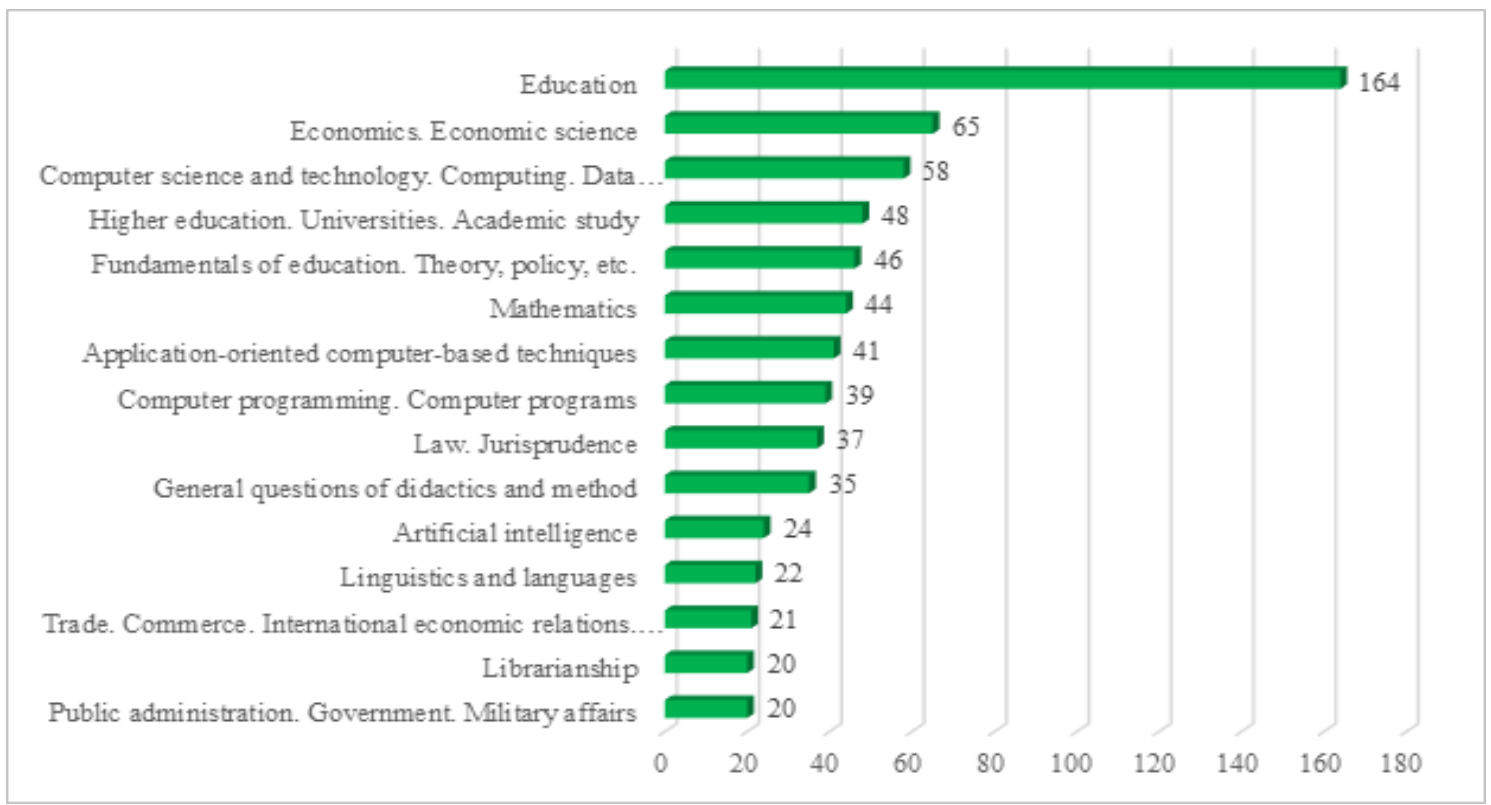

Figure 6. The distribution of documents in NBI by subcategories of the Universal Decimal Classification (Science and Computer Technology, Data Processing)

The analysis of the 496 documents registered in NBI by category according to Universal Decimal Classification subcategories, highlights that the Education field recorded the highest number of publications (33.1\%), followed by Economics (13.1\%) and Economics and Computer Communication (Figure 6). This indicates that the highest number of publications comes from educational institutions rather than from research institutions, but it also highlights the interest for research in applied informatics in the education field.

The selection of a relevant publication type can have a huge effect on the impact and visibility of the published research. Therefore, the analysis of the type of documents used to communicate the research results is of great importance. The Figure 7 presents the distribution of the documents by type.

We identified 5 different types of documents in WoS, the most frequently encountered ones being "Proceedings Paper" (over 53\%), "Article" (almost 45\%) and "Book Chapter" (almost 15\%). The other kinds of documents, such as "Editorials" and "Book reviews" represent a negligible share.

Scopus registers various types of publications, with the most popular ones being "Conference Paper" (62\%) and "Articles" (25\%). Book chapters represent $9 \%$ of all publications and all the other types are insignificant for the research (editorials, articles in press, books and reviews - 4\%).

The analysis of the type of documents recorded in NBI shows that the majority of them fit in the Journal Articles category. There are several explanations to this situation. Firstly, NBI records mostly journals and articles from national journals. Secondly, there are very few conference materials registered in NBI, due to the fact that NBI started recording this type of documents only in October 2017.

If we compare the analysis results of the international databases WoS and Scopus with the NBI results, based on document type, a difference in type hierarchy can be observed (Figure 7). Thus, WoS and Scopus placed conference materials on first place, followed by journal articles. We can conclude that at the international level Moldovan researchers disseminate their research results mostly by participating in scientific conferences. There are also very few international journal publications and there is only one Moldovan journal specialized in Computer Science that is accredited and included in WoS database - "Computer Science Journal of Moldova". 


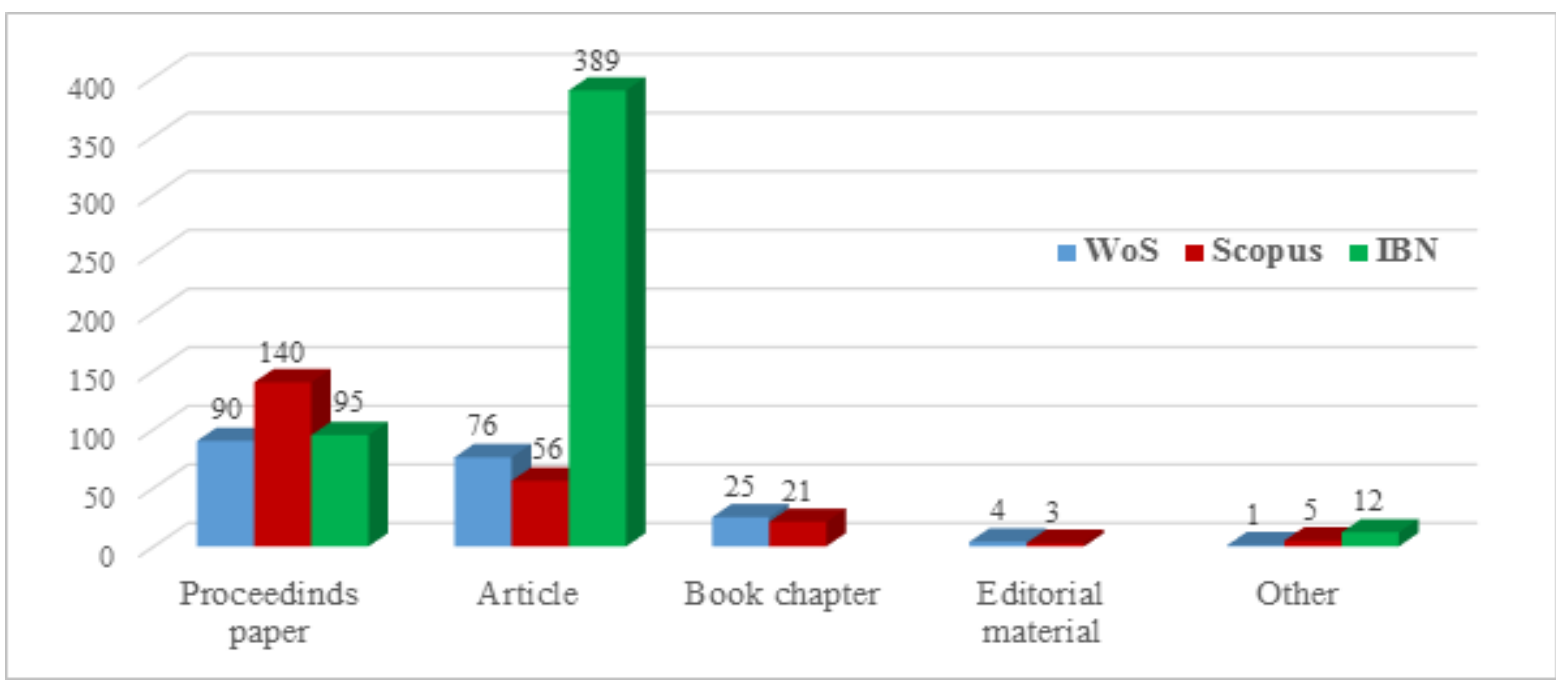

Figure 7. Distribution of documents by type (WoS, Scopus and NBI)

Table 2 presents the distribution of documents by type collected from the Web of Science database. Although, there are much more published papers in the Conference Materials section, the number of citations as well as the average number of citations per document is a lot higher in the Journal Articles category. Out of the 169 documents collected from WoS 90 were cited, with a total of 119 citations and an average of 0.7 citations per document.

Table 2. Document distribution by type (WoS)

\begin{tabular}{|l|c|c|c|c|c|c|}
\hline $\begin{array}{c}\text { Document } \\
\text { Type }\end{array}$ & $\begin{array}{c}\text { Number of } \\
\text { Documents }\end{array}$ & $\%$ & $\begin{array}{c}\text { Number of } \\
\text { Citations }\end{array}$ & $\%$ & $\begin{array}{c}\text { Average Number of } \\
\text { Citations per } \\
\text { Document }\end{array}$ & h-Index \\
\hline $\begin{array}{l}\text { Proceedings } \\
\text { Paper }\end{array}$ & 90 & 53.3 & 49 & 39.2 & 0.5 & 4 \\
\hline Articles & 76 & 45.0 & 70 & 56.0 & 0.9 & 4 \\
\hline Book chapters & 25 & 14.8 & 6 & 6.8 & 0.2 & 1 \\
\hline Editorials & 4 & 2.4 & 0 & & 0 & 0 \\
\hline Book Reviews & 1 & 0.6 & 0 & & 0 & 0 \\
\hline
\end{tabular}

Scopus database reveals a similar situation with WoS, where the number of citations as well as the average number of citations per paper is higher in the case of Articles (Table 3). This data suggests that journal articles are used oftener for research documentation.

Table 3. Document distribution by type (WoS)

\begin{tabular}{|l|c|c|c|c|c|c|}
\hline $\begin{array}{c}\text { Document } \\
\text { Type }\end{array}$ & $\begin{array}{c}\text { Number of } \\
\text { Documents }\end{array}$ & $\%$ & $\begin{array}{c}\text { Number of } \\
\text { Citations }\end{array}$ & $\%$ & $\begin{array}{c}\text { Average Number of } \\
\text { Citations per Docu- } \\
\text { ment }\end{array}$ & h-Index \\
\hline $\begin{array}{l}\text { Conference } \\
\text { papers }\end{array}$ & 140 & 62.2 & 132 & 39.8 & 0.9 & 5 \\
\hline Articles & 56 & 24.9 & 181 & 54.5 & 3.2 & 7 \\
\hline Book chapters & 21 & 9.3 & 0 & 0 & 0 & 0 \\
\hline Editorials & 3 & 1.3 & 0 & 0 & 0 & 0 \\
\hline Article in press & 3 & 1.3 & 0 & 0 & 0 & 0 \\
\hline Books & 1 & 0.4 & 6 & 1.8 & 6.0 & 1 \\
\hline Reviews & 1 & 0.4 & 13 & 3.9 & 13.0 & 1 \\
\hline
\end{tabular}


The share of references to papers in Computer Science with Moldovan authors in the period under review is not very high and fluctuates from $0 \%$ to $1.3 \%$ in $\mathrm{WoS}$ and from $1.5 \%$ to $3.3 \%$ in Scopus (Table 4).

Table 4. Citations distribution by year (WoS \& Scopus)

\begin{tabular}{|c|c|c|c|c|c|c|}
\hline \multirow[b]{2}{*}{ Year } & \multicolumn{3}{|c|}{ WoS } & \multicolumn{3}{|c|}{ Scopus } \\
\hline & $\begin{array}{c}\text { Total Number } \\
\text { of Citations to } \\
\text { Papers from } \\
\text { Moldova } \\
\end{array}$ & $\begin{array}{c}\text { Total Number } \\
\text { of Citations in } \\
\text { Computer } \\
\text { Science } \\
\end{array}$ & $\%$ & $\begin{array}{c}\text { Total Number of } \\
\text { Citations to } \\
\text { Papers from } \\
\text { Moldova } \\
\end{array}$ & $\begin{array}{c}\text { Total Number } \\
\text { of Citations in } \\
\text { Computer } \\
\text { Science } \\
\end{array}$ & $\%$ \\
\hline 2013 & 145 & 0 & 0 & 182 & 6 & 3.3 \\
\hline 2014 & 713 & 6 & 0.8 & 830 & 13 & 1.6 \\
\hline 2015 & 1583 & 21 & 1.3 & 1840 & 50 & 2.7 \\
\hline 2016 & 2399 & 18 & 0.7 & 3395 & 59 & 1.7 \\
\hline 2017 & 3557 & 44 & 1.2 & 5628 & 87 & 1.5 \\
\hline 2018 & 4400 & 21 & 0.5 & 7211 & 106 & 1.5 \\
\hline Total & 12797 & 110 & 0.9 & 19086 & 321 & 1.7 \\
\hline
\end{tabular}

It should be noted that all Moldovan publications for the studied period are cited 12797 times in WoS and 19086 times in Scopus, while the percentage of the citations of publications in the Computer Science field constitutes only $0.9 \%$ in WoS and $1.7 \%$ in Scopus.

It is obvious that the papers in Scopus record a higher number of citations. The distribution of the number of citations by year shows that the highest number of citations in Scopus is registered in 2018 while in WoS in 2017 (Figure 8).

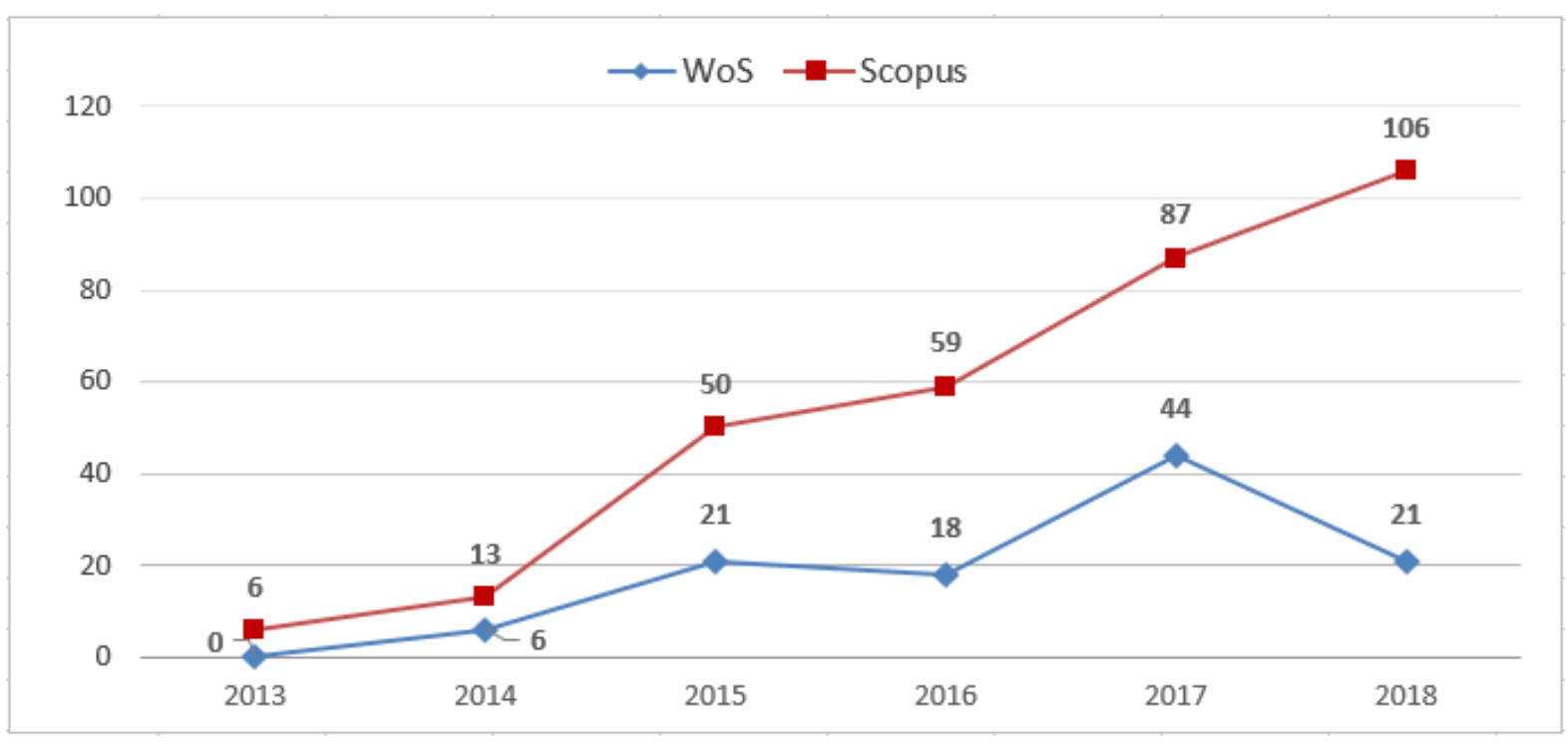

Figure 8. Citations distribution by year (WoS \& Scopus)

The H-index is calculated for establishing the overall value of research publications in a certain science field. Thus, the H-index for the publications from Scopus is 8 , meaning that there are 8 publications in Computer Science, with at least 8 references each. The H-index of Moldovan authors' publications registered in the WoS database in Computer Science field is 7.

In terms of language use, the situation is quite clear. It is well known that WoS is based almost exclusively on publications in English. We can deduct this fact from Table 5, where the percentage of publications in English is $99.4 \%$, and all the recorded references are, as well, to documents 
written in English. In fact, the impact of English publications in terms of citations per article is 0.7. We found no publications in Computer Science by Moldovan authors in Romanian language in the WoS database (Figure 9). The impact of publications in languages other than English is negligible, not only for Moldova. This fact is also proven by the research paper "Computer Science in Eastern Europe 1989-2014: a Bibliometric Study", which found that the percentage of works published in English, as well as the number of citations to articles written in English exceeded 99\% (Fiala\&Willett 2015, p. 4).

Table 5. Distribution of documents by language (WoS \& Scopus)

\begin{tabular}{|l|l|c|c|c|c|c|c|}
\hline Database & $\begin{array}{c}\text { Publishing } \\
\text { Language of } \\
\text { Documents }\end{array}$ & $\begin{array}{c}\text { Number of } \\
\text { Documents }\end{array}$ & $\%$ & $\begin{array}{c}\text { Number of } \\
\text { Citations }\end{array}$ & $\begin{array}{c}\text { Average No } \\
\text { of Citations } \\
\text { per article }\end{array}$ & h-Index \\
\hline \multirow{2}{*}{ WoS } & English & 168 & 99.4 & 112 & 100 & 0.7 & 7 \\
\cline { 2 - 8 } & Russian & 1 & 0.6 & 0 & 0 & 0 & 0 \\
\hline \multirow{2}{*}{ Scopus } & English & 221 & 98.2 & 331 & 99.7 & 1.5 & 8 \\
\cline { 2 - 8 } & Russian & 4 & 1.8 & 1 & 0.3 & 0.2 & 1 \\
\hline
\end{tabular}

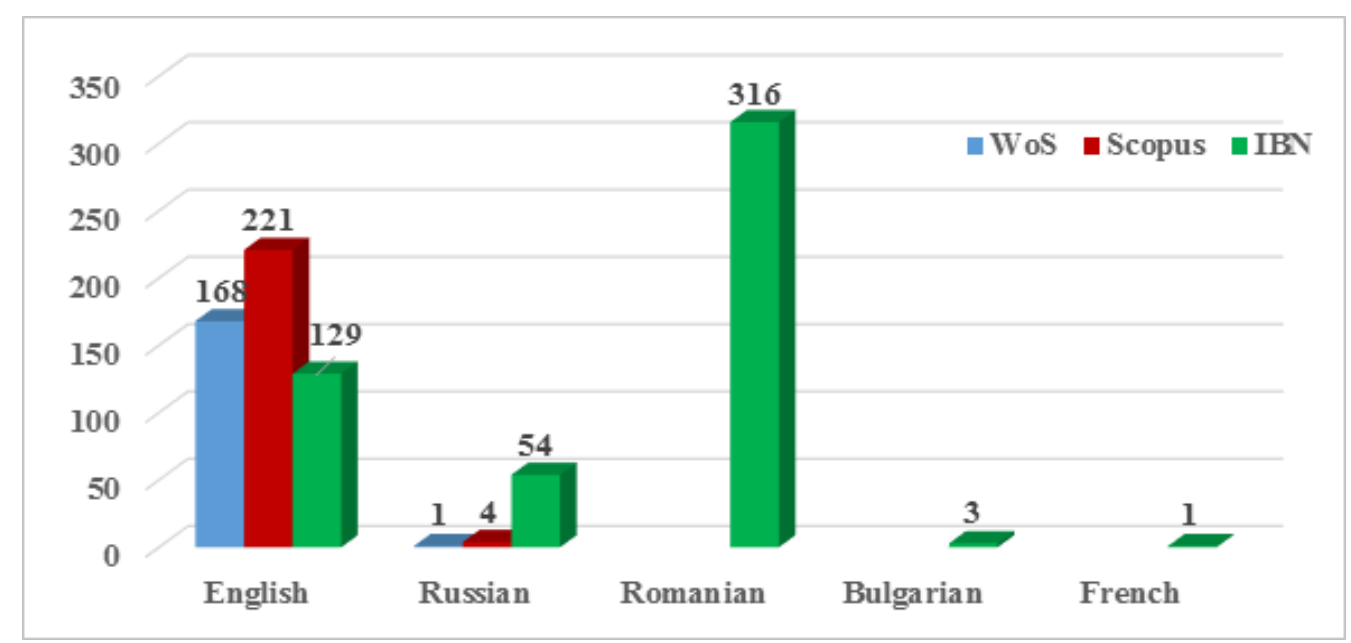

Figure 9. Documents distributed by language of papers (WoS, Scopus, NBI)

The result analysis for 2013-2018 of all WoS papers in Computer Science reveals that 98.9\% $(1,239,827$ publications) are in English, followed by $0.3 \%$ (3,963 publications) in Spanish. Romanian language is positioned $15^{\text {th }}$, with 53 publications relevant to this field $(0.004 \%)$.

Scopus and WoS databases present a very similar situation based on the language the documents are published in. Over 98\% of articles in Computer Science are published in English and only 4 articles $(1.8 \%)$ are in Russian.

The most common languages of papers registered in NBI are Romanian - over $63.7 \%$, English $26 \%$, and Russian $-10.9 \%$ (Figure 9).

Table 6 presents the distribution of the publications in Computer Science in the WoS database by source. 
Table 6. Distribution of documents by publication source (WoS)

\begin{tabular}{|c|l|c|c|}
\hline No & \multicolumn{1}{|c|}{ Source Title } & \multicolumn{1}{|c|}{ No } & $\%$ \\
\hline 1. & Computer Science Journal of Moldova & 34 & 20.1 \\
\hline 2. & Lecture Notes in Computer Science & 16 & 9.5 \\
\hline 3. & $\begin{array}{l}\text { Pareto-Nash-Stackelberg Game and Control Theory. Intelligent Paradigms and Appli- } \\
\text { cations }\end{array}$ & 16 & 9.5 \\
\hline 4. & Smart Innovation Systems and Technologies & 16 & 9.5 \\
\hline 5. & E Health and Bioengineering Conference & 14 & 8.3 \\
\hline 6. & Roedunet International Conference & 8 & 4.7 \\
\hline 7. & Proceedings of International Conference on Virtual Learning & 7 & 4.1 \\
\hline 8. & Lecture Notes in Educational Technology & 6 & 3.5 \\
\hline 9. & User Interface Design of Digital Textbooks, How Screens Affect Learning & 6 & 3.5 \\
\hline 10. & $\begin{array}{l}\text { CSCS20-2015 (2015 20 }{ }^{\text {th }} \text { International Conference on Control Systems and Computer } \\
\text { Science) }\end{array}$ & 5 & 3.0 \\
\hline 11. & $\begin{array}{l}\text { EHB 2017 (IEEE 2017 International Conference on E-Health and } \\
\text { Bioengineering Conference) }\end{array}$ & 5 & 3.0 \\
\hline 12. & Membrane Computing, CMC 2014 & 5 & 3.0 \\
\hline 13. & Other Sources & 31 & 18.3 \\
\hline
\end{tabular}

As mentioned above, one of the most important sources for papers with Moldovan authors in the field is "Computer Science Journal of Moldova" (34 articles) published by Vladimir Andrunachievici Institute of Mathematics and Computer Science. "Lecture Notes in Computer Science" is positioned on the second place, with twice fewer articles (16 articles). "Lecture Notes in Computer Science” used to be a leader between 2001-2012, with 38 articles.

We find that about two-thirds of Scopus publications are materials of various conferences. The distribution of documents by source is presented in Table 7. The largest number of documents was published in the Proceedings of SPIE The International Society for Optical Engineering (34 documents); Lecture Notes in Computer Science (33 papers) that included the Lecture Notes in Artificial Intelligence and Lecture Notes in Bioinformatics; Smart Innovation Systems and Technologies (15 documents).

Table 7. Distribution of documents by publication source (Scopus)

\begin{tabular}{|c|l|c|c|}
\hline No & \multicolumn{1}{|c|}{ Source Title } & No & \% \\
\hline & Proceedings of SPIE The International Society For Optical Engineering & 34 & 12.6 \\
\hline & $\begin{array}{l}\text { Lecture Notes in Computer Science including Subseries Lecture Notes in Arti- } \\
\text { ficial Intelligence and Lecture Notes in Bioinformatics }\end{array}$ & 33 & 12.3 \\
\hline & Smart Innovation Systems and Technologies & 15 & 5.6 \\
\hline & 2015 E Health and Bioengineering Conference EHB 2015 & 9 & 3.3 \\
\hline & Advances in Intelligent Systems and Computing & 8 & 3.0 \\
\hline & Optical Materials & 7 & 2.6 \\
\hline & $\begin{array}{l}\text { Proceedings of the Romanian Academy Series a Mathematics Physics Techni- } \\
\text { cal Sciences Information Science }\end{array}$ & 6 & 2.2 \\
\hline & Theoretical Computer Science & 6 & 2.2 \\
\hline & $\begin{array}{l}\text { International Conference Recent Advances in Natural Language Processing } \\
\text { RANLP }\end{array}$ & 5 & 1.9 \\
\hline & Lecture Notes in Educational Technology & 5 & 1.9 \\
\hline & $\begin{array}{l}\text { Proceedings 2015 20th International Conference on Control Systems and Com- } \\
\text { puter Science CSCS 2015 }\end{array}$ & 5 & 1.9 \\
\hline & Proceedings Roedunet IEEE International Conference & 5 & 1.9 \\
\hline & Other sources & 87 & 32.3 \\
\hline
\end{tabular}




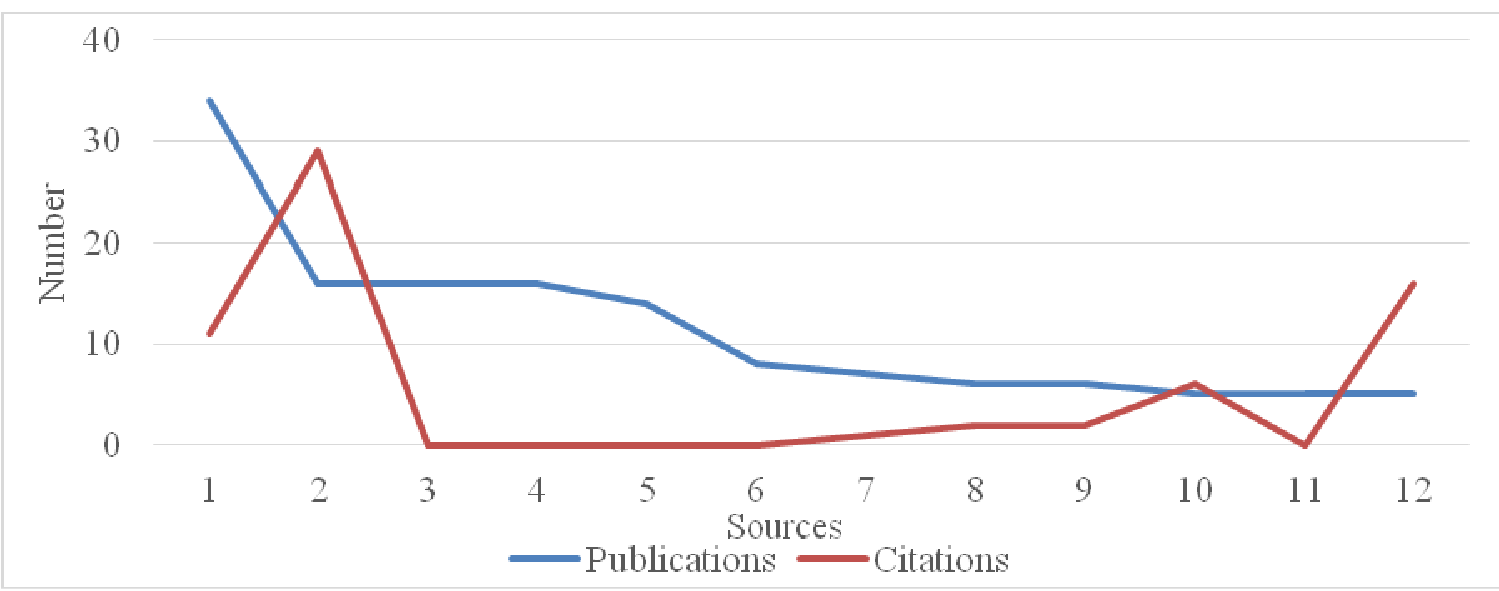

Figure 10. Number of Publications VS Number of Citations (WoS)

(Source titles are presented in the Table 6)

The analysis of the total number of publications vs total number of citations for the top sources in Computer Science field shows that the bigger number of publications does not result in the bigger number of citations. Figure 10 presents data from WoS, while Figure 11 shows data from Scopus.

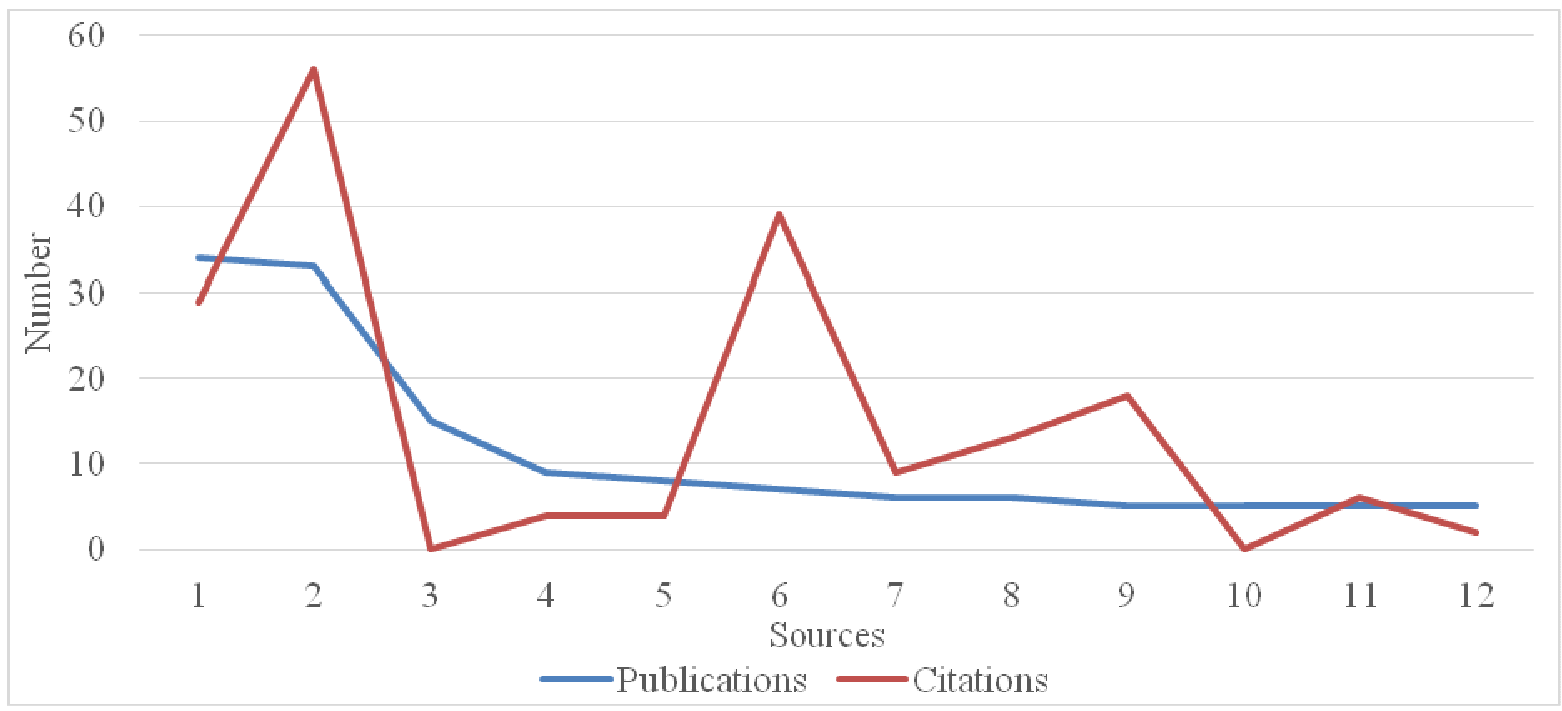

Figure 11. Number of Publications VS Number of Citations (Scopus)

(Source titles are presented in the Table 7)

Figure 12 illustrates the distribution of publication sources of articles in the Computer Science field registered in NBI.

Similar to the analysis of documents by the NBI domains or the Universal Decimal Classification domains, we observe that the first two positions belong to educational journals. The number of articles in these journals highlights that there is a significant interest in applicative Computer Science research in Education Science. There are only five top sources directly related to Computer Science field:

- Computer Science Journal of Moldova (26 articles) and Akademos journal (22 articles) accredited in the Information Science field;

- Intellectus journal (20 articles) and Engineering Meridian journal (18 articles) - accredited in Engineering Science and Technology field;

- Information Technologies, Systems and Networks Conference materials (22 articles). 


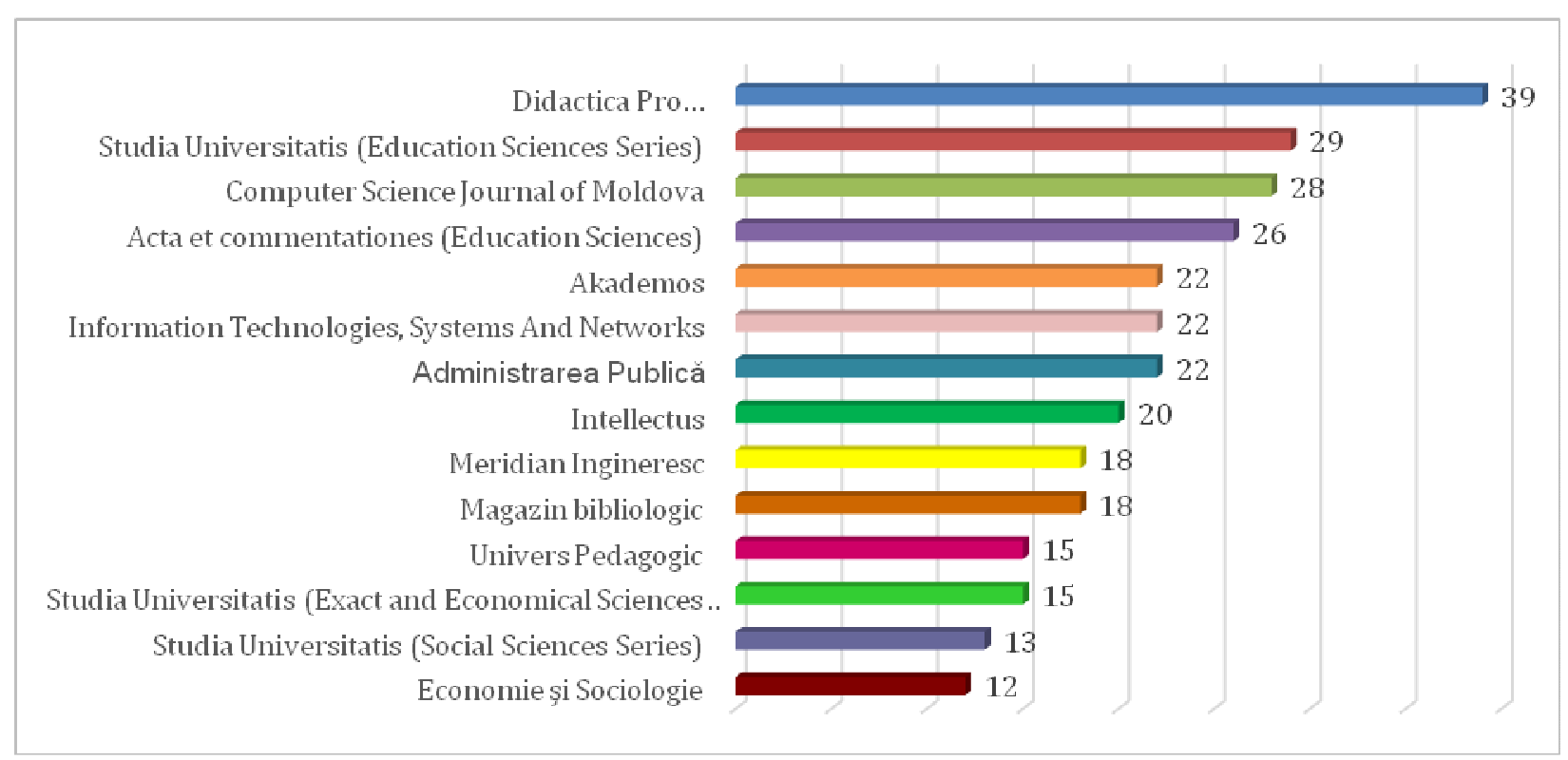

Figure 12. Document distribution by publication source (NBI)

A brief analysis of the conference theses recorded in NBI shows that there are papers related to Artificial Intelligence, the Internet of Things, Robotics and other subjects that are relevant to Moldova's Smart specialization.

As mentioned above, the research impact of Moldovan authors' in Computer Science is fairly low, in both number of articles and number of citations per article. Based on bibliometric studies, the top positions belong to China and USA (based on the number of publications), as well as to Great Britain, Switzerland, the Netherlands and Israel (based on the average number of citations per article) (Fiala and Tutoky 2017). One of the goals of our research was to observe the extent to which authors from the Republic of Moldova collaborate with researchers from the most influential countries in Computer Science (Figure 13).

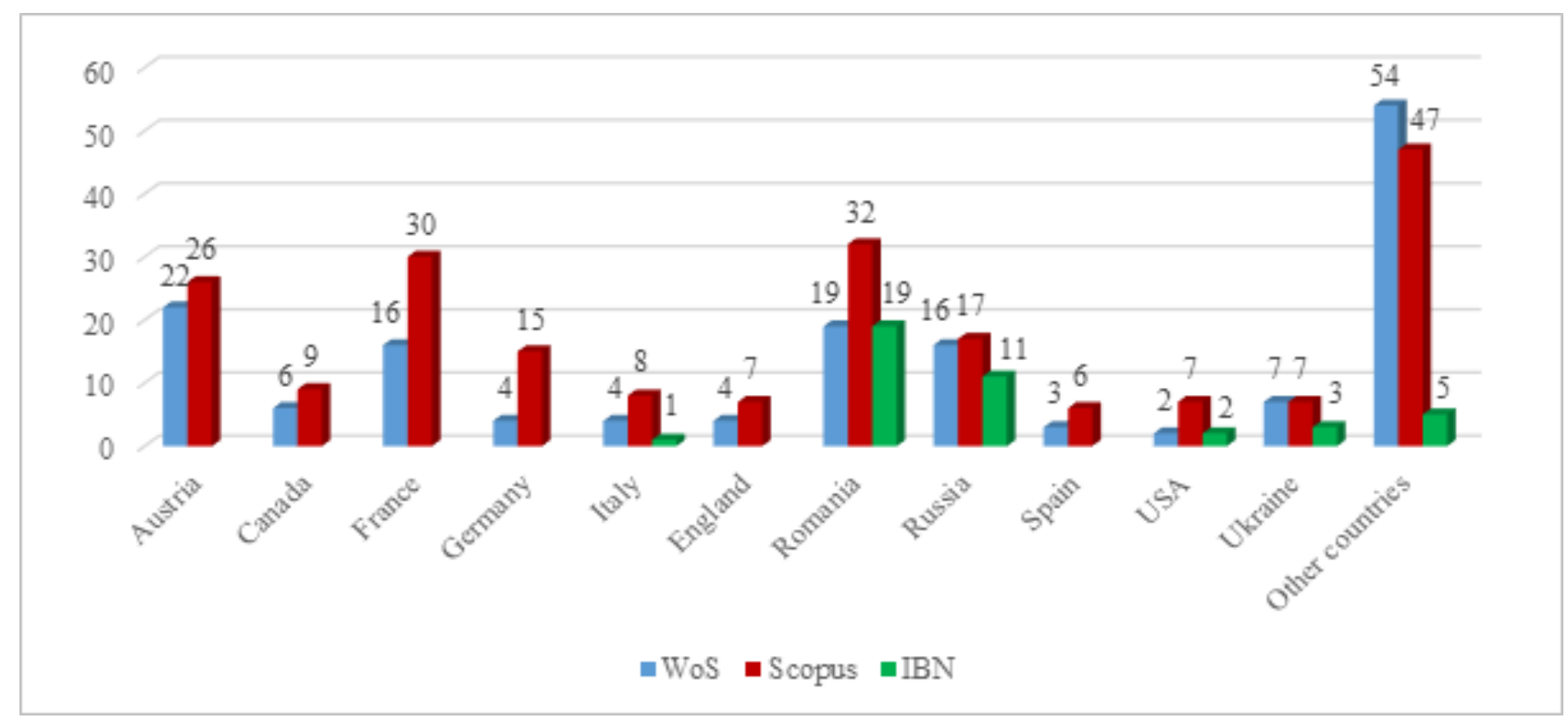

Figure 13. Publishing collaboration of authors from Moldova in Computer Science in 2013-2018 (WoS, Scopus, NBI)

We noticed that the collaboration of Moldovan authors with top countries in Computer Science research based on WoS database is minimal. There are only 2 recorded publications written in cooperation with authors from USA and 4 publications - with authors from Great Britain. The 
most collaborative publications are written with authors from Austria (22 - 13\%); Romania (19 11.2\%); France (16 - 9.5\%), Russia (16 - 9.5\%).

Data from Scopus reveals that authors from Moldova prefer to collaborate mostly with the same countries. Thus, according to Scopus, the highest number of co-authoring works are registered with authors from Romania (32 works - 14.2\%), France (32 - 13.3\%), Austria (26 - 11.6\%), Russia $(17-7.6 \%)$ and Germany $(15-6.7 \%)$.

As per data from NBI, Moldovan authors collaborate most frequently with authors from Romania (19 works), Ukraine (3), Israel (4), and USA (2). At the same time the number of publications written in collaboration with authors from abroad is smaller.

At an institutional level (Table 8), according to WoS database in the Computer Science field the leading position belongs to the Academy of Sciences of Moldova (ASM) with one third of documents $(33.7 \%)$. Other institutions that contribute to publications in Computer Science field are: Technical University of Moldova (17.2\%), Moldova State University (16.6\%), Vladimir Andrunachievici Institute of Mathematics and Computer Science (8.3\%), RENAM (7.1\%).

Table 8. Distribution of papers in Computer Science by Moldovan author affiliation in 2013-2018 (WoS)

\begin{tabular}{|l|c|c|c|c|c|c|}
\hline \multicolumn{1}{|c|}{ Institution Affiliation } & $\begin{array}{c}\text { Number of } \\
\text { Documents }\end{array}$ & $\%$ & $\begin{array}{c}\text { No of } \\
\text { Citations }\end{array}$ & \% & $\begin{array}{c}\text { Citations } \\
\text { per } \\
\text { Article }\end{array}$ & $\begin{array}{c}\text { h- } \\
\text { index }\end{array}$ \\
\hline Academy of Sciences of Moldova (ASM) & 57 & 33.7 & 78 & 69.6 & 1.4 & 6 \\
\hline Technical University of Moldova (TUM) & 29 & 17.2 & 13 & 11.6 & 0.4 & 2 \\
\hline Moldova State University (MSU) & 28 & 16.6 & 5 & 4.5 & 0.2 & 2 \\
\hline $\begin{array}{l}\text { Vladimir Andrunachievici Institute of } \\
\text { Mathematics and Computer Science } \\
\text { (IMCS) }\end{array}$ & 14 & 8.3 & 2 & 1.8 & 0.1 & 1 \\
\hline RENAM Association & 12 & 7.1 & 0 & 0 & 0 & 0 \\
\hline State University of Tiraspol (SUT) & 9 & 5.3 & 3 & 2.7 & 0.3 & 1 \\
\hline $\begin{array}{l}\text { "Ion Creangă" State Pedagogical Univer- } \\
\text { sity of Chisinau (SPU) }\end{array}$ & 8 & 4.7 & 3 & 2.7 & 0.4 & 1 \\
\hline $\begin{array}{l}\text { University of European Studies of } \\
\text { Moldova (UESM) }\end{array}$ & 7 & 4.1 & 2 & 1.8 & 0.3 & 1 \\
\hline $\begin{array}{l}\text { Academy of Economic Studies of } \\
\text { Moldova (AESM) }\end{array}$ & 6 & 3.6 & 0 & 0 & 0 & 0 \\
\hline $\begin{array}{l}\text { Nicolae Testemitanu State University of } \\
\text { Medicine and Pharmacy }\end{array}$ & 6 & 3.6 & 0 & 0 & 0 & 0 \\
\hline
\end{tabular}

According to data from WoS, the Academy of Sciences of Moldova has the highest number of citations (69.6\%), as well as the highest number of average citations per article - 1.4 (Table 8). Based on article citations data, ASM is followed by TUM (11.6\%) and MSU (4.5\%).

Scopus shows that at the institutional level the leading position belongs, again, to the Academy of Sciences of Moldova (Table 9). The analysis reveals that almost half (45.3\%) of all works belong to this institution. Other affiliations to authors from Moldova with international publications in Computer Science are: Technical University of Moldova (24.4\%); Vladimir Andrunachievici Institute of Mathematics and Computer Science (18.2\%); Institute of Applied Physics (16.4\%); Moldova State University (13.3\%). 
Table 9. Distribution of papers in Computer Science by Moldovan author affiliation in 2013-2018 (Scopus)

\begin{tabular}{|l|c|c|}
\hline \multicolumn{1}{|c|}{ Institution Affiliation } & $\begin{array}{c}\text { Number of } \\
\text { Documents }\end{array}$ & $\%$ \\
\hline Academy of Sciences of Moldova (ASM) & 102 & 45.3 \\
\hline Technical University of Moldova (TUM) & 55 & 24.4 \\
\hline $\begin{array}{l}\text { Vladimir Andrunachievici Institute of Mathematics and Computer Science } \\
\text { (IMCS) }\end{array}$ & 41 & 18.2 \\
\hline Institute of Applied Physics (IAPh) & 37 & 16.4 \\
\hline Moldova State University (MSU) & 30 & 13.3 \\
\hline RENAM Association & 10 & 4.4 \\
\hline State University of Tiraspol (SUT) & 9 & 4.0 \\
\hline Academy of Economic Studies of Moldova (AESM) & 5 & 2.2 \\
\hline University of European Studies of Moldova (UESM) & 5 & 2.2 \\
\hline
\end{tabular}

In NBI the authors with the highest number of articles in Computer Science are affiliated to the Moldova State University (87 documents), followed by ones affiliated to the Academy of Economic Studies of Moldova (66 documents), the State University of Tiraspol (41 documents), Vladimir Andrunachievici Institute of Mathematics and Computer Science (37 documents) and the Technical University of Moldova (35 documents) (Figure 14).

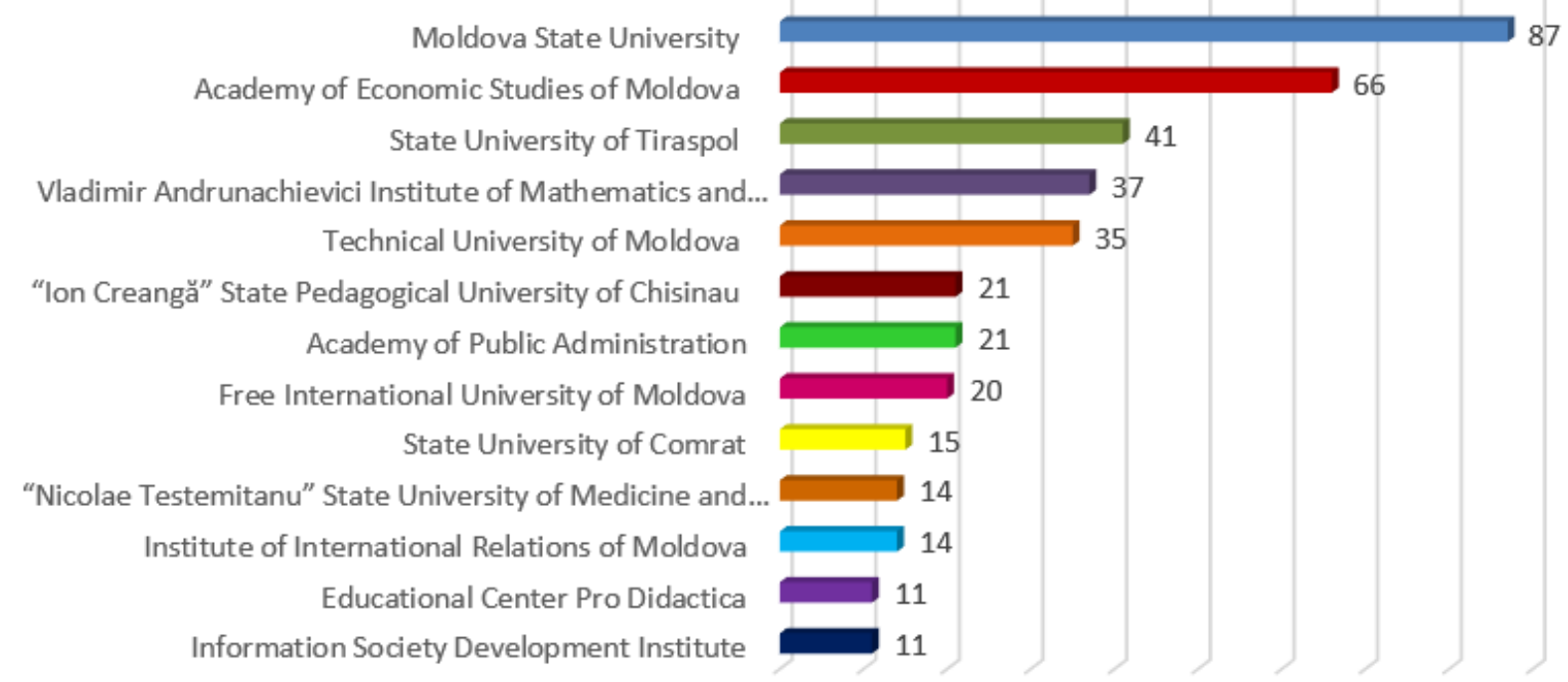

Figure 14. Distribution of documents by author affiliation (NBI)

The publications in the Computer Science field from the WoS database were analysed also from the authors' perspective, identifying the most prolific Moldovan authors (Table 10). It was found that the most productive authors are Artiom Ahazov (27 articles, affiliated to IMCS), Valeriu Ungureanu (19 articles, represents MSU), Petru Bogatencov (13 articles, from RENAM), and Svetlana Cojocaru (12 articles, affiliated to IMCS). 
Table 10. Distribution of documents and citations by authors (WoS)

\begin{tabular}{|l|c|c|c|c|c|c|}
\hline $\begin{array}{c}\text { Author, Institutional } \\
\text { Affiliation }\end{array}$ & $\begin{array}{c}\text { Number of } \\
\text { Documents }\end{array}$ & $\%$ & $\begin{array}{c}\text { Number of } \\
\text { Citations }\end{array}$ & $\%$ & $\begin{array}{c}\text { Average No } \\
\text { of Citations } \\
\text { per Article }\end{array}$ & $\begin{array}{c}\text { h- } \\
\text { index }\end{array}$ \\
\hline Alhazov Artiom, IMCS & 27 & 16.0 & 55 & $\begin{array}{c}49 . \\
1\end{array}$ & 2.0 & 5 \\
\hline Ungureanu Valeriu, MSU & 19 & 11.2 & 4 & 3.6 & 0.2 & 2 \\
\hline Bogatencov Petru, RENAM & 13 & 7.7 & 0 & 0 & 0 & 0 \\
\hline Cojocaru Svetlana, IMCS & 12 & 7.1 & 3 & 2.7 & 0.2 & 1 \\
\hline Secrieru Grigore, RENAM & 9 & 5.3 & 0 & 0 & 0 & 0 \\
\hline Railean Elena, SUT & 8 & 4.7 & 2 & 1.8 & 0.2 & 1 \\
\hline Rogozin Iurii, IMCS & 6 & 3.5 & 6 & 5.4 & 1 & 2 \\
\hline Bobicev Victoria, TUM & 5 & 3.0 & 6 & 5.4 & 1.2 & 1 \\
\hline Colesnicov Alexandru, IMCS & 5 & 3.0 & 1 & 0.9 & 0.2 & 1 \\
\hline Malahova Ludmila, IMCS & 5 & 3.0 & 1 & 0.9 & 0.2 & 1 \\
\hline Iliuha Nicolai, RENAM & 5 & 3.0 & 0 & 0 & 0 & 0 \\
\hline Burțeva Ludmila, IMCS & 4 & 2.4 & 0 & 0 & 0 & 0 \\
\hline Cojocaru Victor, ASM & 4 & 2.4 & 2 & 1.8 & 0.5 & 1 \\
\hline
\end{tabular}

Table 11 presents top authors from Moldova of papers in Computer Science, registered in Scopus database. The top authors with the highest number of publications are Artiom Alhazov (40 articles) from IMCS, with the most citations to his works (28.9\%), Valeriu Ungureanu (16 articles) affiliated MSU, 12 articles belong to Petru Bogatencov (RENAM), Victoria Bobicev (TUM) and Mihai Iovu (IAPh).

Table 11. Distribution of documents and citations by authors (Scopus)

\begin{tabular}{|l|c|c|c|c|c|c|}
\hline $\begin{array}{c}\text { Author, Institutional } \\
\text { Affiliation }\end{array}$ & $\begin{array}{c}\text { Number of } \\
\text { Documents }\end{array}$ & $\%$ & $\begin{array}{c}\text { Number of } \\
\text { Citations }\end{array}$ & $\%$ & $\begin{array}{c}\text { Average No of } \\
\text { Citations per } \\
\text { Article }\end{array}$ & h-Index \\
\hline Alhazov Artiom, IMCS & 40 & 17.8 & 96 & 28.9 & 2.4 & 6 \\
\hline Ungureanu Valeriu, MSU & 16 & 7.1 & 1 & 0.3 & 0.1 & 1 \\
\hline Bogatencov Petru, RENAM & 12 & 5.3 & 7 & 2.1 & 0.6 & 1 \\
\hline Bobicev Victoria, TUM & 12 & 5.3 & 32 & 9.6 & 2.7 & 2 \\
\hline Iovu Mihai, IAPh & 12 & 5.3 & 9 & 2.7 & 0.7 & 2 \\
\hline Rogozin Iurii, IMCS & 10 & 4.4 & 35 & 10.5 & 3.5 & 2 \\
\hline Cojocaru Svetlana, IMCS & 8 & 3.6 & 2 & 0.6 & 0.2 & 1 \\
\hline Secrieru Grigore, RENAM & 8 & 3.6 & 4 & 1.2 & 0.5 & 1 \\
\hline Lupan Oleg, TUM & 7 & 3.1 & 11 & 3.3 & 1.6 & 2 \\
\hline Railean Elena, SUT & 7 & 3.1 & 0 & 0 & 0 & 0 \\
\hline
\end{tabular}

Top authors based on data from NBI is presented in Figure 15. The most publications belong to: Svetlana Cojocaru (14 documents), Elena Badarau ( 9 documents), Octombrina Moraru (8 documents). 


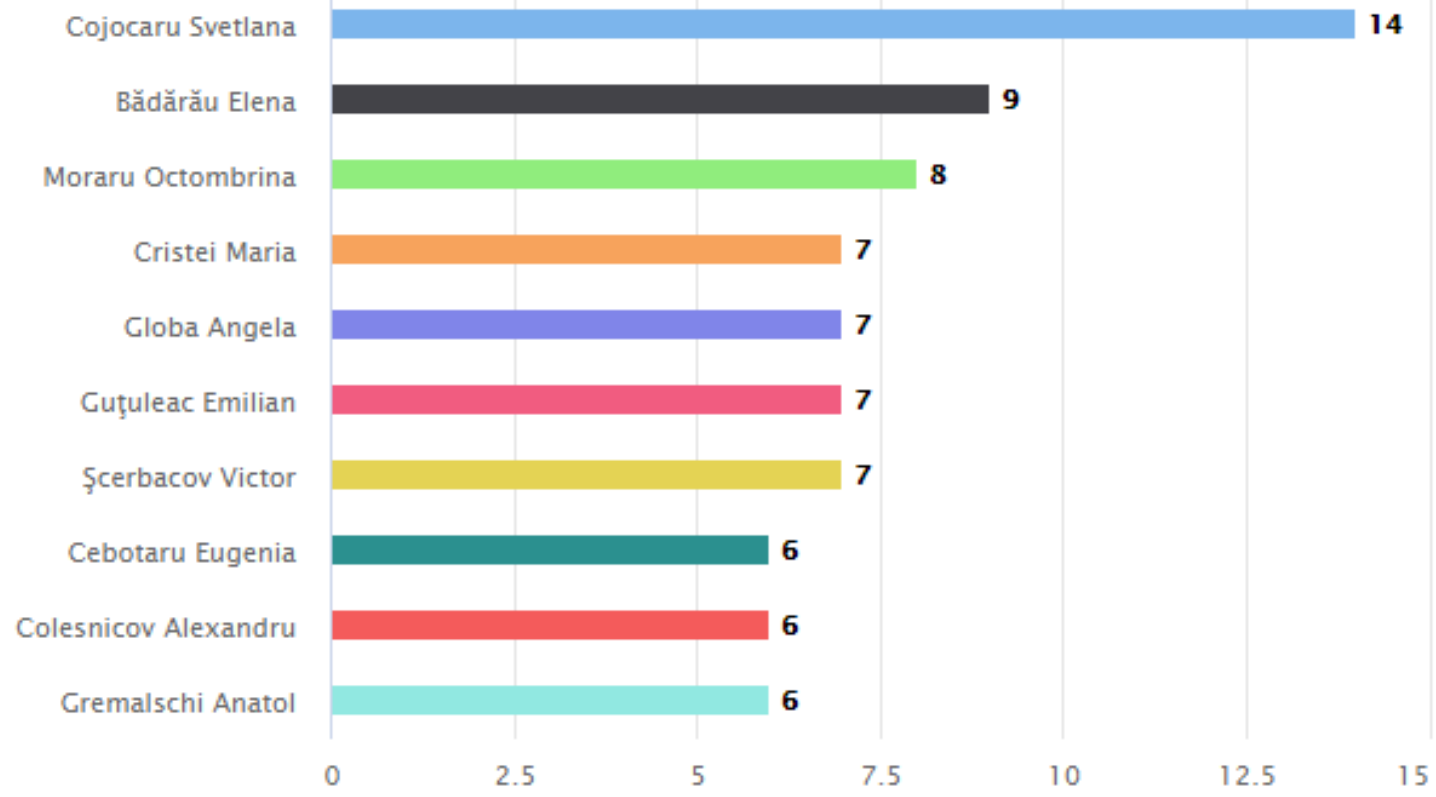

Figure 15. Top authors with the highest number of publications (NBI)

Scopus and NBI databases allow for filtering and analysis of results based on keywords. Table 12 unravels the keywords used the most in all Computer Science publications with Moldovan authors. The top keywords found in Scopus are: artificial intelligence (27 publications), nanotechnology (25), P-system (25). NBI presents the following most used keywords: information technology(ies) (35 publications), internet (21) and e-learning (12).

Table 12. Keyword Frequency in Papers on Computer Science in 2013-2018 (Scopus \& NBI)

\begin{tabular}{|l|c|l|c|}
\hline \multicolumn{1}{|c|}{ Keyword } & $\begin{array}{c}\text { Number of } \\
\text { Records in } \\
\text { Scopus }\end{array}$ & \multicolumn{1}{|c|}{ Keyword } & $\begin{array}{c}\text { Number of } \\
\text { Records in } \\
\text { IBN }\end{array}$ \\
\hline artificial intelligence & 27 & information technology(ies) & 35 \\
\hline nanotechnology & 25 & Internet & 21 \\
\hline P systems & 25 & e-learning & 12 \\
\hline microelectronics & 21 & evaluation & 11 \\
\hline optoelectronic devices & 21 & information & 9 \\
\hline bioinformatics & 20 & technology & 9 \\
\hline computation theory & 17 & communication & 8 \\
\hline computer science & 15 & education & 8 \\
\hline computational completeness & 13 & security & 7 \\
\hline computers & 11 & software & 8 \\
\hline
\end{tabular}

The degree of collaboration between authors represents an important analysis for bibliometric studies. It shows the trend of a single authored model as well as multi-authored researches in the studied period. Some researchers (Maharana\&Sethi 2013) consider that the degree of collaboration that is very close to 1 means that the efforts and contribution of some authors are insignificant or negligible. 
For determining the degree of collaboration in quantitative terms, we used the following formula suggested by K. Subramanyan (1983).

$$
C=\frac{N m}{N m+N s}
$$

Where:

$$
\begin{aligned}
& \boldsymbol{C} \text { - Degree of Collaboration } \\
& \boldsymbol{N s} \text { - Number of Single authored papers } \\
& \boldsymbol{N m} \text { - Number of Multi authored papers }
\end{aligned}
$$

As shown in the Table 13, the degree of collaboration $\boldsymbol{C}$, for all publications in Computer Science fields is 0.71 (according to WoS) and 0.8 (according to Scopus). As a result, we can ascertain that the degree of collaboration in the Computer Science field is relatively high 0.71-0.80 and the majority of published documents is predominantly multi authored.

Table 13. The Degree of Collaboration of authors from Moldova in Computer Science Field (WoS \& Scopus)

\begin{tabular}{|l|c|c|c|c|}
\hline \multicolumn{1}{|c|}{ Database } & Ns & Nm & Ns + Nm & C \\
\hline WoS & 49 & 120 & 169 & 0,71 \\
\hline Scopus & 46 & 179 & 225 & 0,8 \\
\hline
\end{tabular}

The data collected from WoS and Scopus, allows us to identify the average contribution of the Moldovan authors to all the published documents in the Computer Science field, as well as the average number of authors per article (Table 14). According to WoS, a total of 572 authors published 169 articles, with an average of 3.38 authors per article and 0.3 publications per author. As per the data originating from Scopus database, a total of 818 authors published 225 articles, with an average of 3.64 authors per article and 0.28 publications per author.

Table 14. Author productivity (WoS \& Scopus)

\begin{tabular}{|l|c|c|c|c|}
\hline \multicolumn{1}{|c|}{ Database } & $\begin{array}{c}\text { Total Number of } \\
\text { Articles }\end{array}$ & $\begin{array}{c}\text { Total Number } \\
\text { of Authors }\end{array}$ & $\begin{array}{c}\text { Average Number } \\
\text { of Authors } \\
\text { per Article }\end{array}$ & $\begin{array}{c}\text { Author } \\
\text { Productivity }\end{array}$ \\
\hline WoS & 169 & 572 & 3.38 & 0.3 \\
\hline Scopus & 225 & 818 & 3.64 & 0.28 \\
\hline
\end{tabular}

Documents analysis by the type of access, demonstrates that NBI is an open resource that permits access, visualization and download of any registered scientific publication. Figure 16 shows the distribution of documents by type of access, and reveals that $96.2 \%$ of all documents have open access. In contrast, only 37 publications in Computer Science $(21.9 \%)$ belonging to Moldovan authors recorded in WoS in 2013-2018 can be accessed openly. Scopus allows open access to only 7 documents (3.11\%) of Moldovan authors from Computer Science domain (Figure 16). 


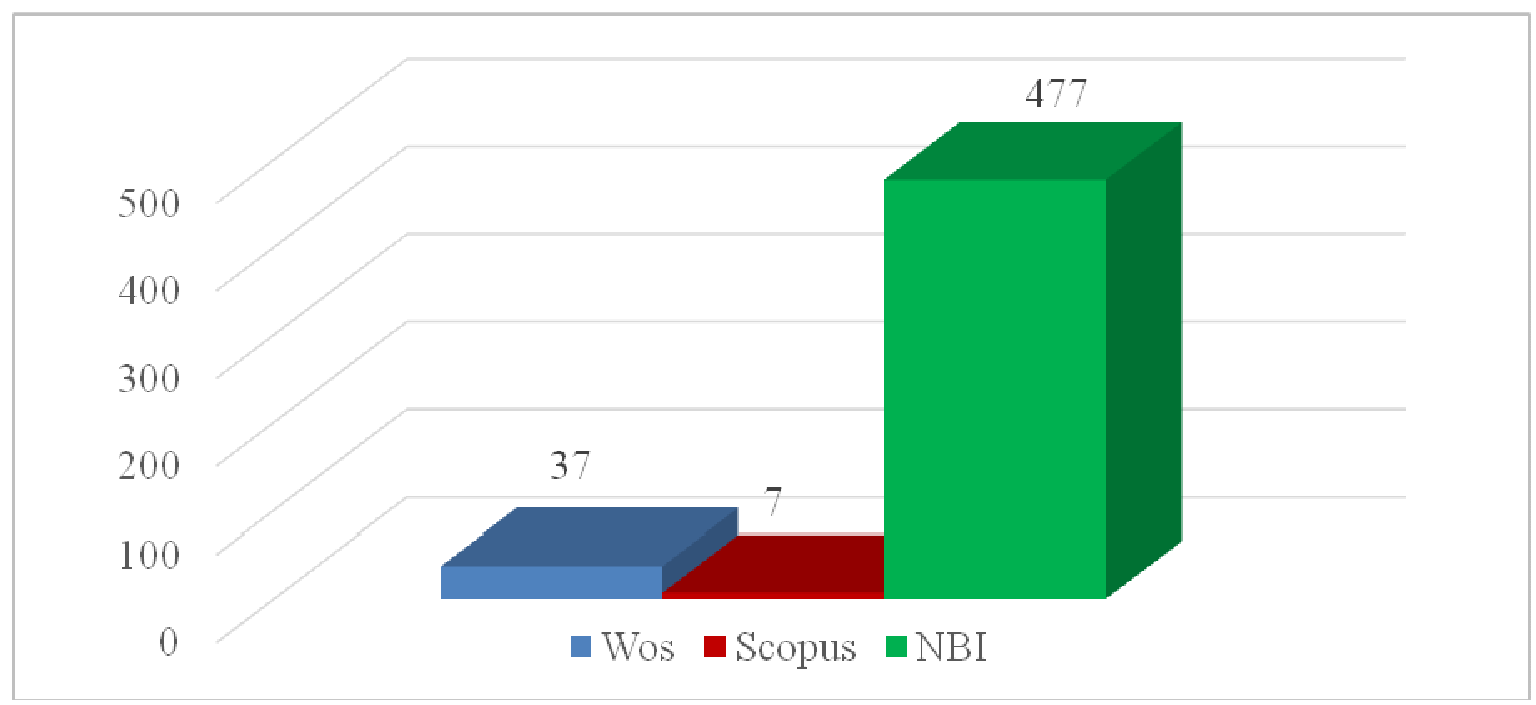

Figure 16. Documents by type of access

\section{Conclusions}

Using data from two international databases (WoS and Scopus) and one national database (NBI), the authors of this paper carried out a study regarding research in Computer Science in the Republic of Moldova. Important parameters such as the total number of published documents in Computer Science, publication growth rate and trends as well as the impact of Computer Science research have been analysed. The authors also took into consideration top institutions and authors from Moldova, as well as scientific conferences and journals.

The study demonstrated that the percentage of Computer Science publications in Moldova between 2013 and 2018 is low - 5\% in WoS, 7.7\% in Scopus and 1.9\% in NBI. Nevertheless, looking at the dynamics of the recorded publications in all three databases, we identified a positive trend, which shows that there is a growing interest in computer science research. The number of publications in this field has increased 6 times according to WoS, over 2.5 times according to Scopus and around 1.5 times based on NBI data.

According to WoS the two most popular subjects in the field, with the highest number of published documents, are Theory \& Methods (45\%) and Artificial Intelligence (26.6\%). Scopus shows that Computer Science articles mostly overlap with fields such as Mathematics (46.2\%) and Engineering (44.4\%). NBI reveals that one third of the publications in Computer Science belong to the Education subcategory (33.1\%), followed by the Economy subcategory (13.1\%). This proves that most of the publications come from the educational institutions and fewer from the research institutes, as well as the high interest in research on the application of computer science in education.

The international articles in Computer Science published by Moldovan authors are not very influential. There were 110 citations of their works recorded in WoS, with an average of 0.65 citations per article, while Scopus database has registered 331 citations of Moldovan research documents, with an average of 1.43 citations per article.

Based on the publication source, according to data from WoS, Computer Science Journal of Moldova is the main source were Moldovan academia publish their research in Computer Science (34 published articles). Scopus places Proceedings of SPIE The International Society for Optical Engineering on the first place (34 documents), followed by Lecture Notes in Computer Science (33 documents). At national level, the two sources with the highest number of publications are the pedagogical journals - Didactica Pro (39 articles) and Studia Universitatis Moldaviae (29 articles).

According to international databases, the degree of collaboration of authors from Moldova is 
relatively high (0.71-0.80). Moldovan authors cooperate with researchers from various countries such as: Romania, France, Austria, Germany etc. However, the number of publications written in collaboration with countries that are considered influential in computer science is minimal.

At an institutional level, the leading position in Computer Science belongs to the Academy of Sciences of Moldova. The other few institutions with a high contribution to the Computer Science field are: Technical University of Moldova, Moldova State University and Vladimir Andrunachievici Institute of Mathematics and Computer Science.

This growing interest for research in Computer Science shows that there is certain human potential that can contribute to the smart specialization of the country in computer science. At an international level, the most prolific authors are Artiom Ahazov, Valeriu Ungureanu, Petru Bogatencov and Svetlana Cojocaru. Nationally, the authors with the highest number of publications in Computer Science are Cojocaru Svetlana, Bădărău Elena and Moraru Octombrina.

The open source policy promoted by a number of research institutions and universities from Moldova showed positive results; hence $96 \%$ of all documents published by Moldovan authors in NBI can be openly accessed. Internationally, the percentage of open access research publications is relatively low $-21.9 \%(\mathrm{WoS})$ and $2.7 \%$ (Scopus).

\section{Note}

1. For selecting ICT publications from WoS database, we used criteria mentioned in the Research in Information and Communication Technology in Norway: Bibliometric analysis (Aksnes 2012).

\section{References}

Aksnes, D.W. (2012) Research in Information and Communication Technology in Norway: Bibliometric analysis, Oslo: The Research Council of Norway, available: http://bit.ly/rrbsi22019a [accessed 20 March 2019].

Arruda, D., Bezerra, F., Neris, V.A., de Torro, P. R. and Wainer, J. (2009) Brazilian computer science research: gender and regional distributions, Scientometrics, 79(3) pp. 651-665, available: https://doi.org/10.1007/s11192-007-1944-0.

Bakri, A. and Willett, P. (2011) Computer science research in Malaysian universities: a bibliometric analysis, Aslib Proceedings, 63(2/3) pp. 321-335, available: https:// doi.org/10.1108/00012531111135727.

Chadegani, A.A. et al. (2013) A Comparison between Two Main Academic Literature Collections: Web of Science and Scopus Databases, Asian Social Science, 9(5) pp. 18-26, available: https:// doi.org/10.5539/ass.v9n5p18.

Clarivate Analytics (2019) Web of Science, available: https://clarivate.com/products/web-ofscience/ [accessed 9 March 2019].

Cujba, R. (2019) Abordarea bibliometrică în analiza dinamicii de dezvoltare a științei și societăţii [Bibliometric approach in analysis of science and society development], Akademos, 52(1) pp. 2428, available: https://doi.org/10.5281/zenodo.2905426.

Elsevier B.V. (2019) Scopus, available: https://www.scopus.com/ [accessed 9 February 2019]. European Commission (2019) Information and communication technologies, available: https:// ec.europa.eu/regional_policy/en/policy/themes/ict/ [accessed 20 March 2019].

Fiala, D. (2012) Bibliometric analysis of CiteSeer data for countries, Information Processing and Management, 48(2) pp. 242-253, available: https://doi.org/10.1016/j.ipm.2011.10.001. 
Research in Computer Science in The Republic of Moldova: A Bibliometric Analysis

Fiala, D. and Tutoky, G. (2017) Computer Science Papers in Web of Science: A Bibliometric Analysis, Publications, 5(4), 23, available: https://doi.org/10.3390/publications5040023.

Fiala, D. and Willett, P. (2015) Computer science in Eastern Europe 1989-2014: a bibliometric study, Aslib Journal of Information Management, 67(5) pp. 526-541, available: https:// doi.org/10.1108/AJIM-02-2015-0027.

Guan, J. and Ma, N. (2004) A comparative study of research performance in computer science, Scientometrics, 61(3) pp. 339-359, available: https://doi.org/10.1023/

B:SCIE.0000045114.85737.1b.

Gupta, B.M., Kshitij, A. and Verma, C. (2011) Mapping of Indian computer science research output, 1999-2008, Scientometrics, 86(2) pp. 261-283, available: https://doi.org/10.1007/s11192010-0272-y.

Heidari, H., Razavi, F., Mousakhani, M. and Zandi, Y.G. (2017) A scientometric analysis of big data literature, 5th Iranian Joint Congress on Fuzzy and Intelligent Systems (CFIS), 7-9 March 2017, available: https://doi.org/10.1109/CFIS.2017.8003654.

Heilig, L. and Voß, S. (2014) A Scientometric Analysis of Cloud Computing Literature, IEEE Transactions on Cloud Computing, 2(3) pp. 266-278, available: https://doi.org/10.1109/ TCC.2014.2321168.

Hollanders, H. (2017) Mapping of economic, innovative and scientific potential in the Republic of Moldova: Summary of the report „Mapping of economic, innovative and scientific potential in the Republic of Moldova", available: http://bit.ly/rrbsi22019b [accessed 20 March 2019].

Institutul de Dezvoltare a Societății Informaționale (2019) Instrumentul Bibliometric Național [National Bibliometric Instrument], available: https://ibn.idsi.md/ [accessed 8 February 2019].

Institutul de Dezvoltare a Societăţii Informaționale (2019) Știu.md, available: http://stiu.md/ [accessed 11 February 2019].

International Data Corporation (2018) Worldwide ICT Spending Including New Tech Expected to Exceed \$5.6 Trillion in 2021, According to New IDC Black Book, available: http://bit.ly/ rrbsi22019c [accessed 20 March 2019].

Karanatsiou, D., Misirlis, N. and Vlachopoulou, M. (2017) Bibliometrics and altmetrics literature review: Performance indicators and comparison analysis, Performance Measurement and Metrics, 18(1) pp. 16-27, available: https://doi.org/10.1108/PMM-08-2016-0036.

Ma, R., Ni, C. and Qiu, J. (2008) Scientific research competitiveness of world universities in computer science, Scientometrics, 76(2) pp. 245-260, available: https://doi.org/10.1007/s11192007-1913-7.

Maharana, R.K. and Sethi, B.B. (2013) A bibliometric analysis of the research output of Sambalpur University's publication in ISI Web of Science during 2007-11, Library Philosophy and Practice, 926, available: http://digitalcommons.unl.edu/libphilprac/926/ [accessed 3 March 2019].

Mayr, P. and Scharnhorst, A. (2015) Scientometrics and information retrieval: weak-links revitalized, Scientometrics, 102(3), pp. 2193-2199, available: https://doi.org/10.1007/s11192-0141484-3.

Ministerul Economiei și Infrastructurii (2018) Sectorul TIC a înregistrat cea mai mare creștere din ultimii opt ani [The ICT sector has seen the highest growth in the last eight years], available: http://bit.ly/rrbsi22019d [accessed 20 March 2019].

Price, D. (1951) Quantitative Measures of the Development of Science, Archives Internationales d'Histoire de Sciences, 14 pp. 86-93, available: http://bit.ly/rrbsi22019e [accessed 9 March 2019]. 
Qinghua, H. et al. (2017) Mapping the managerial areas of Building Information Modeling (BIM) using scientometric analysis, International Journal of Project Management, 35(4) pp. 670-685, available: https://doi.org/10.1016/j.ijproman.2016.08.001.

Singh, V.K., Banshal, S.K., Singhal, K. and Uddin, A. (2015a) Scientometric mapping of research on 'Big Data', Scientometrics, 105(2) pp. 727-741, available: https://doi.org/10.1007/s11192-0151729-9.

Singh, V.K., Uddin, A. and Pinto, D. (2015b) Computer science research: the top 100 institutions in India and in the world, Scientometrics, 104(2) pp. 529-553, available: https://doi.org/10.1007/ s11192-015-1612-8.

Subramanyam, K. (1983) Bibliometric Study of Research Collaboration: A Review, Journal of Information Science, 6(1) pp. 33-38, available: https://doi.org/10.1177/016555158300600105.

Technologies.org. (2018) Global IT Spending to Grow 6.2 Percent in 2018, State of the IT Market, available: https://www.technologies.org/?p=2371 [accessed 20 March 2019].

Uddin, A. and Singh, V.K. (2014) Mapping the Computer Science Research in SAARC Countries, IETE Technical Review, 31(4) pp. 287-296, available: https:// doi.org/10.1080/02564602.2014.947527.

Uddin, A., Singh, V.K., Pinto, D. and Olmos, I. (2015) Scientometric mapping of computer science research in Mexico, Scientometrics, 105(1) pp. 97-114, available: https://doi.org/10.1007/ s11192-015-1654-y.

Wainer, J., Xavier, E.C. and Bezerra, F. (2009) Scientific production in Computer Science: A comparative study of Brazil and other countries, Scientometrics, 81(2) pp. 535-547, available: https://doi.org/10.1007/s11192-008-2156-y.

Xie, Z. and Willett, P. (2013) The development of computer science research in the People's Republic of China 2000-2009: a bibliometric study, Information Development, 29(3) pp. 251-264, available: https://doi.org/10.1177/0266666912458515.

Zhao, X. (2017) A scientometric review of global BIM research: Analysis and visualization, Automation in Construction, 80 pp. 37-47, available: https://doi.org/10.1016/j.autcon.2017.04.002. 